University of Rhode Island

DigitalCommons@URI

Open Access Master's Theses

1987

\title{
A COMPARATIVE ANALYSIS FOR THE REEVALUATION OF RHODE ISLAND CRITICAL AREAS PROGRAM
}

Mahkameh Adnani

University of Rhode Island

Follow this and additional works at: https://digitalcommons.uri.edu/theses

\section{Recommended Citation}

Adnani, Mahkameh, "A COMPARATIVE ANALYSIS FOR THE REEVALUATION OF RHODE ISLAND CRITICAL AREAS PROGRAM" (1987). Open Access Master's Theses. Paper 503.

https://digitalcommons.uri.edu/theses/503

This Thesis is brought to you for free and open access by DigitalCommons@URI. It has been accepted for inclusion in Open Access Master's Theses by an authorized administrator of DigitalCommons@URI. For more information, please contact digitalcommons-group@uri.edu. 


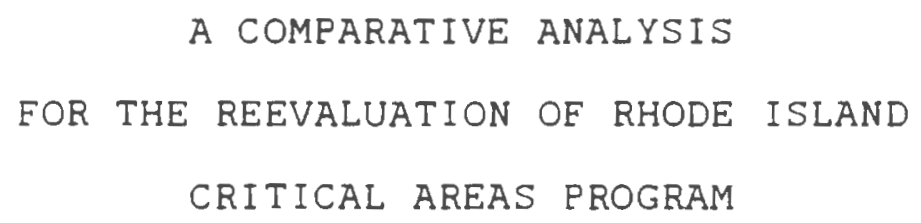




\section{MASTER OF COMMUNITY PLANNING}

RESEARCH PROJECT

OF

MAHKAMEH ADNANI

Approved:

Major professor

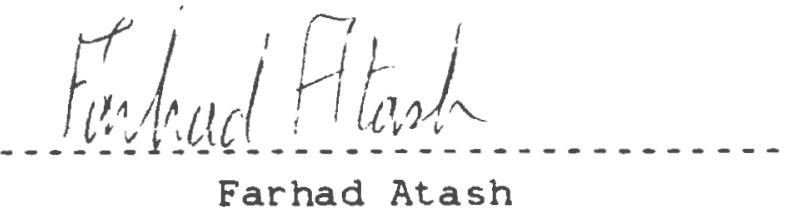

Acknowledged:

Director

Howard H. Eoster, Jr. 


\section{DEDICATION}

To my family, Mahin, Manoucher, and Hedieh Adnani. 


\section{ACKNOWLEDGEMENTS}

I Would like to sincerely thank my thesis advisor, Earhad Atash for his continuous assistance and patience. And special thanks to Howard Foster and the CPAD department for the invaluable support throughout the program. 


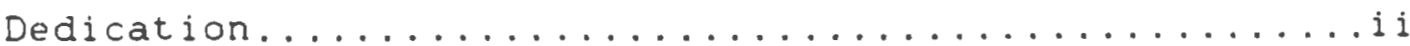

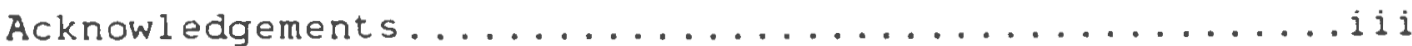

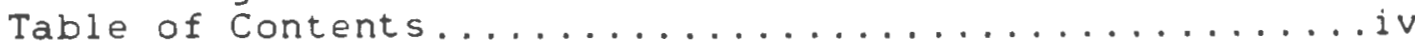

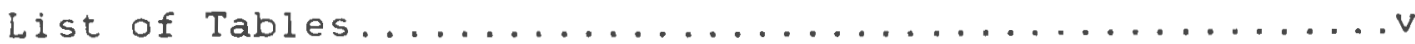

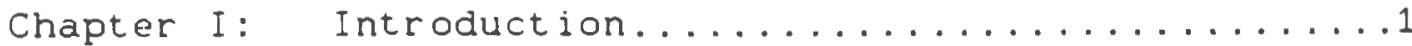

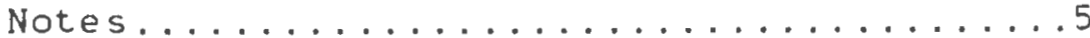

Chapter II: The Florida Experience...............

Nature of the Problems in Elorida........

Form of State-local Relationship........12

Administrative Agency Structure........13

Definition of Critical Areas..........14

Designation of Critical Areas.........15

Regulation of Critical Areas.........17

Constitutional Provisions...........18

Implementation. ................28

Developments of Regional Impact........35

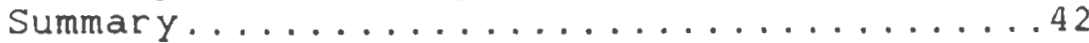

Notes.....................47

Chapter III: The Rhode Island Critical

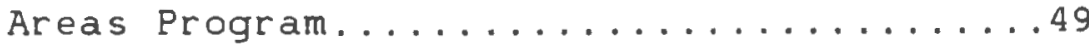

Eorm of State-local Relationship........50

Administrative Structure..............51

Definition of Critical Areas..........52

Designation of Critical Areas.........58

Regulation of Critical Areas..........60

Constitutional Provisions...........61

Summary.....................662

Issues and Conflicts.............64

Notes.......................... 72

Chapter IV: A Comparative Analysis and Summary of

Recommendations....................73

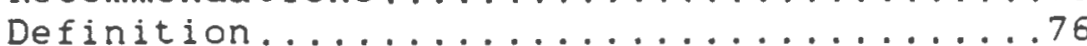

State-local Relationship............78

Administrative Structure.............81

Designation..................84

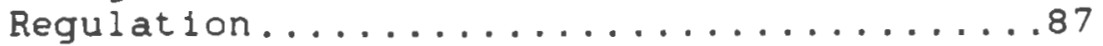

Constitutional Provisions............89

Summary of Recommendations...........990

Notes.........................955

Bibliography........................... 


\section{LIST OF TABLES}

TABLE

PAGE

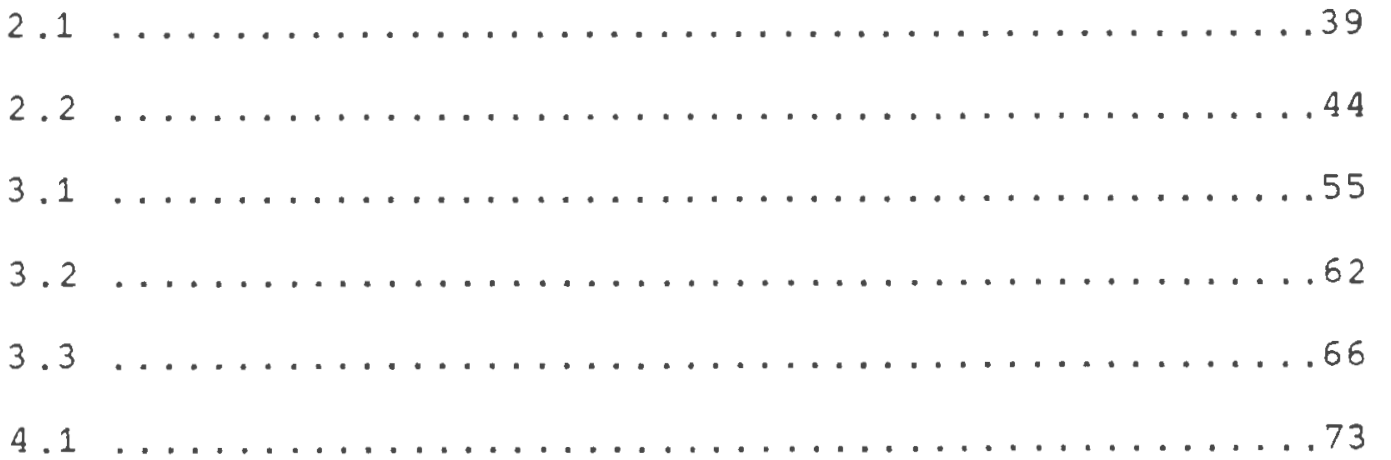


Chapter I

INTRODUCTION

Controls over the use of land are the prerogative of local government. Prior to $1970^{\circ} \mathrm{s}$, states had little involvement in land use decision-making except in review of court cases. The $1970^{\circ}$ s were witness to a "Quiet Revolution" in land use control when innovative legislation was passed in many states. A number of states initiated a movement that attempted to change the traditional institutional arrangements and began to introduce a new role for the state in land use planning and control. This movement was supported by the general public whose serious concerns for environmental protection and regulatory centralization was rapidly rising. It was time to reassess the need for a more collaborative system of land use decision-making and growth management and implementation between the various levels of government. Despite the persistent effort of local governments in dealing with urbanization and in controlling the impact of growth upon the environment, the existing local mechanism, in many instances, was proven deffective and inadequate.

Today, the early momentum of state land use control is lost. However, the various state programs that were adopted in the $1970^{\circ} \mathrm{s}$ remain strong and active which suggest that a reevaluation of the state's role in land use control and comprehensive planning is called for.

The critical areas provisions have been a major 
component of land management legislation across the United States. They have been adopted by the states to assist the local governments in controlling the negative or positive multi-jurisdictional impact of growth upon the local communities and regions. Therefore, a greater degree of state intervention in land use decision-making is becoming increasingly crucial to the protection of land and natural resources and health, safety, and general welfare of a broader public. There are four specific areas in which state involvement is suggested to be highly important:

"1) when there are problems that cross the boundaries of existing levels of jurisdictions and do not confine themselves neatly to municipal or county entities;

2 ) where there are problems created from the actions of a local body which may result in a negative impact of the interest of the broader public;

3) when there are lands which have limited local control that do not effectively protect the land resource of the state; and

4) and problems or conflicts involving implementation of state policies or fund." 1

This points to the need for state oversight of municipal planning actions and the need for proper goal assessment and implementation at the local level.

This study attempts to once again bring attention to the need for state land use management, especially in a rapidy growing state with invaluable natural and environmental resources such as in the state of Rhode Island. The land management legislation which included a critical areas provision was first proposed in 1974 but was never passed by the Rhode Island General Assembly. The 
reason for the failure of the bill was due partially to substantive or procedural shortcomings of the legislation but mainly to the state-local and public-private sector conflicts.

The objective of this study is to determine the shortcomings of the Rhode Island proposed program and the extend of its political conflicts and propose recommendations in terms of improvements of the procedural requirements and implementation strategies. This is accomplished by reviewing and evaluating the state of Florida Areas of Critical State Concern provision, a major component of the Environmental Land and Water Management Act of 1972, and by carrying out a comparative analysis of the two programs. The Florida critical areas program is an instructive model due to its fifteen years of implementation and it is therefore an appropriate measure by which the Rhode Island program can be evaluated.

This study is comprised of four chapters. Chapter I is a description and evaluation of the Environmental Land and Water Management Act of 1972 and 1 ts two components, the Areas of Critical State Concern (ACSC) program and the Development of Regional Impact (DRI) program. Although the emphasis of this study is on the critical areas program, the DRI program was worthy of inclusion. Despite a common objective of controliing the growth impacts upon areas that extend beyond the local jurisdiction, these programs differ in terms of process. The 
DRI program calls for the state's reaction rather than the state's initiative in assessing development impacts. Thus, the evaluation of the DRI program and its implementation process was also included.

This chapter begins with a description of the definition, form of state-local relationship, designation, regulation, and constitutional provisions of the Florida critical areas program. This is followed by a qualitative and quantitative assessment of the implementation process for both the ACSC and the DRI programs.

Chapter III, summarizes the proposed Rhode IsIand critical areas program. The chapter is composed of two sections. Similar to chapter II, firstly, a descriptive analysis is presented. The second section is a brief description of issues relative to the state-local and public-private sector conflicts and a summary of proposed recommendations by the Rhode Island Builders Association (RIBA) and the Rhode Island Chamber of Commerce.

Chapter IV, compares the Florida critical areas program and the Rhode Island proposed program to reveal shortcomings of the Rhode Island program and to propose recommendations which will be summarized at the end of the chapter. 
$N O T E S$

1. Robert G, Healy, LAND USE AND THE STATES, $1979, p .6$ 
Chapter II

THE ELORIDA EXPERIENCE

Although fundamental land use decisions still remain at the local level, several states, depending upon the nature and immediacy of their problems, have initiated their own programs and regulations. Inevitably, this greater exercise of states' power has caused controversies and thus states have attempted to resolve the state-local conflict by directing their programs toward better cooperation and coordination among state, regional, and local governing bodies. Also, better provision of information and assistance to local agencies has been the major objective rather than an attempt to eliminate local input and to ignore local influence and power. "When provided information on outcomes, nearly all people will act in their best interest".

As previously mentioned, some states have felt the urgent need to take immediate action in assisting and directing the municipalities. The demand for proper state regulations has emerged as a result of serious concerns for environmental protection, loss of prime agriculture land, preservation of natural resources, suburbanization and unplanned development, and other problems associated with rapid growth.

The state of Florida is one of the first states that has taken serious and elaborate courses of action in state land use control. It has initiated state programs and 
regulations to overcome the resource mismanagement at the local level and to assist municipalities in coping with rapid urbanization.

This chapter will examine the extent and nature of state land use planning and control in Florida, with the emphasis on the critical areas program as a major component of the Environmental Land and Water Management Act of 1972 .

- NATURE OF THE PROBLEMS IN FLORIDA

The rate and scale of Florida's growth has been phenomenal since 1950. In the period between 1950 to 1976 , when U.S. population grew by some 40\%, Florida's population tripled, increasing from 2.8 million in 1950 to 8.5 million in 1976. This phenomenal rate of increase moved Florida from twentieth to eighth in population across the country. By 1980, the population had increasd to almost 9.8 million, and Florida ranked seventh in the nation in population. By the end of 1981, the population had exceeded 10 million and Florida was reaching the 1990 projected population of between 12 to 13 million, at which time it will rank fourth in the United States.

This growth has been also the result of a massive inmigration due to the unique climatological and geographical features of the state. "Since 1970, Florida has had a net in-migration rate that is three times as great as any other state in the nation". Florida, therefore, has been one the fastest growing states for much of the past two decades and its "growth in the $1980^{\circ} \mathrm{s}$ is predicted to be. twice that of 
the Sunbelt and three times the national average". However, this massive growth has been concentrated in few regions while most of the state's interior has experienced stagnation or decline. The negative impact of this unbalanced growth on the ir igile nature of most Florida's envirciment and the emergence of large-scale developments have been the two major factors leading to the demand for proper growth management and control at the state level.

Eragile and Unique Environment

Florida, especially the southern portion, $p$ is ss: $=s$ the richest areas of tropical life in the continental United States, and the most unique and diverse ecological system of all.

"As elsewhere in the tropics, Florida's natural environment is dependent on a web of interrelationships, woven from the interaction of different forms of life or the interaction of living things and the land that supports them. In so delicately balanced a system, removing of one element can have serious and far-reaching consequences". 5

Undoubtedly, the massive growth in southern Florida has caused imbalances in the natural system, particularly in the water system, the key to much of Florida's natural and human life (subsurface water is the source of 90 percent of water used in the state). The imposition of such a growth rate has resulted in water and air pollution, destruction of wildife habitat, flooding, saltwater intrusion and the like. The reason lies in the desirability and thus high prices of waterfront land and consequently the building of 
high-rises as the best solution to more access to the water. The increased population density in the waterfront and other environmentally sensitive areas has brought all the common problems associated with unplanned growth such as pollution. Also, the growth pressures and the demand for land has resulted in the filling of wetlands. The transformation of these natural purification systems has greatly contributed to local flooding and destruction of wildife habitats, that of several rare or endangered species.

High Density Development

The high prices of land and the developers desire to make development even more profitable have been the major factors contributing to the demand for higher densities and the popularity of planned-unit developments, residential clusters, town houses, and the garden apartments. Plannedunit developments have been particularly successful as they provide a variety of housing types along with extensive commercial and recreational facilities. Thus, much of Florida's growth is channeled into few gigantic large-scale development.

The housing market is inclined toward the retiree and second-home buyers. In fact, southern florida has become the recipient of numerous second-home communities and gradually has turned into a retirement center. To accommodate this vast market, large subdivisions have been developed. Many of them are located in environmentally sensitive areas such as coastal wetlands, swamps, and marshes and have caused 
irrepairable damages to their surrounding natural environment.

More specifically four major environmental events led to a new attitude and a new statutory and institutional framework for growth management: " the effort to construct a barge canal across the northern end of the peninsula; threats to the water supply of Everglades National Park; the effort to build a major regional jetport in the Big Cypress - Swamp in western Dade and eastern Collier counties, and the increasingly obvious abuses of the land sales craze in the $1950^{\prime} \mathrm{s}$ and $1960^{\circ} \mathrm{s} "$.

The cross-state barge canal project was finally stopped by an environmental group called the Florida Defenders for the Environment who undertook an environmental impact study and brought the canal project to an actual end after 20 miles of Oklawaha River had been destroyed by the building of a dam.

The Everglades National Park water issue was a classic conflict between protecting the urban water supply as against protecting the natural ecology of the park since the initial policy was to maximize capacity. In 1970, Congress authorized funding for the central and southern Florida Flood Control project, conditional to 315,000 acre feet of annual water for the park when the enlargement of the Miami Canal was completed. This successful effort illustrated the growing political power of the national environmental groups which was a major element in the effectiveness of critical areas legislation and similar 
state programs.

The jetport project in south Florida was also abandoned by the Dade County Port Authority after 21 environmental groups and two labor unions objected to the proposal. The environmental impact statement concluded that while the jetport site itself would not have a major impact on the flow of water through the Big Cypress to the swamps, the inevitable urban development would in fact have a major 8 negative impact.

The undesirable impact of such rapid urbanization and growth did gradually bring attention to necessary changes in state policies. There was a serious need for environmentally responsive growth management policies and programs. Apart from the negative growth impacts, the new politics of Florida resulting from the legislative reapportionment created a political balance between the growth area in southern Florida and the political center in the north.Also, the new constitution of 1968 for the first time in the state's history gave a general of home rule and power to both cities and counties, easing the process of adopting a new legislation.

In 1970, the state of Florida began to consider the approach taken by the American Law Institute (ALI) Model Land Development Code. "The ALI Model Code... left most land use decisions to local governments, while providing a way to reflect any regional and state interests involved in those decisions". 10 The state concentrated on 
the Code's Article 7 which proposes recommendations for the protection of interests that extend beyond the local jurisdictions. In 1972, the Elorida Environmental Land and Water Management Act, which was part of a legislative package of four bills, the Florida State Comprehensive Planning Act of 1972, the Land Conservation Act of 1972, and the Water Resources Act of 1972, was passed with a rather similar language to the ALI Code. In general, the Law requires state designation and regulation of critical areas of statewide significance (Areas of Critical State Concern) and the state regulation of large-scale developments with more than local impact (Developments of Regional Impact). "The state can reassert its authority over land use and reserve the right to overrule local governments whose land use decisions fail to take into consideration the more-than-local impacts of development".

FORM OF STATE-LOCAL RELATIONSHIP

In general, the critical areas programs emphasize the emerging role of states in the process of land use regulation and control when it is beyond the power and ability of local governments to protect and regulate areas of statewide or regional importance.

"The use of critical areas represents a workable method of initiating state (or regional) involvement in a field in which almost all responsibilities has been delegated to local government for half a century or more. State interests in the development and use of land can be beneficial to the extend that problems which 
are not adequately solved at the local level are addressed and solved or at least ameliorated". 12

It is very important, however, that a proper system of state-local relationship would be established so to minimize redundancy in the planning functions."... This state interest must be exercised without simply duplicaing local actions at another level, without increasing the cost of land development unnecessarily, and without creating time consuming and innefficient procedure for making land use 13

decisions". Therefore a proper collaboration of state and local governments is deemed necessary in the effectiveness of such programs.

The Model Land Development Code recommends local government implementation of state policies as the appropriate approach to a sound state-local system of relationship. However, depending upon the states governmental tradition, there are variety of approaches ranging from extreme local governments authority to little or no role for local governments. In Florida, the Model Code guideline is followed where local governments implement state approved regulations.

ADMINISTRATIVE AGENCY STRUCTURE

To perform the task of designating and regulating areas of statewide importance, the establishment of an administrative agency is required. As mentioned in the last chapter, the Model Land Development Code recommends the establishment of a state land planning agency in the 
governor's office. In larger states, the agency is allowed to divide itself into several regional planning divisions in order to increase its control over the areas of statewide significance. The governor may also appoint state and regional advisory commissions consisting of professionals, private citizens, and officials of other state agencies or local governments. This pattern is adopted by the state of Florida where the Environmental Land Management Study Committee acts as the state advisory commission and it consists of representatives from various land use interest groups. The Florida statute also requires the involvement of regional planning agencies which function above the local but below the state level. They are not to be compared with the regional planning divisions which are branches of the state planning agency.

To hear the appeals, the ALI Model Code requires the appointment of a land development adjudicatory board by the governor or the highest court. Florida has established the Florida Land and Water Adjudicatory Commission as the appellate board.

DEEINITION OF CRITICAL AREAS

Critical areas are defined based upon the special needs of each state. The ALI Model Code's definition is broad enough to allow for different interpretation among the states and generally introduces three major categories of critical areas: 1) resource areas including areas affecting 
or affected by key facilities such as airports or land areas adjacent to the railroad stations, and sites for new communities; 2) developments of state or regional benefit such as four-season resorts; and 3) large-scale developments such as shopping centers.

Florida's definition is similar to the Model Code definition and includes:

a) an area containing, or having a significant impact upon environmental, historical, natural, or archeological resources of regional or statewide importance;

b) an area significantly affected by, or having a significant effect upon, an existing or proposed major public facilities or other areas of major public investment; and

c) a proposed area of major development potential, which may include a proposed site of a new community, designated in a state land development plan. 14

There is one major factor added to Florida's definition which limits the designation of critical areas to only $5 \%$ of the total land area of the state.

\section{DESIGNATION OF CRITICAL AREAS}

In order to enforce the critical areas legislation, it is crucial to formulate a designation process that properly meets the definitions of critical areas. The procedure for critical areas designation, as recommended by the ALI Model Code, is that the "state planning agency designates the critical areas by rule, specifying the boundaries of a designated area, the reasons it is to be considered critical, the danger of uncontrolled or incompatible development, the advantages of coordinated 
development, general principles for guiding development, and the development to be permitted pending the adoption of regulation and giving notice to affected local 15 Recommendations of areas to be included may governments". Recommendations of areas to be included may be submitted to the Administration Commission by the Division of State Planning, by any regional planning agency, or by a local government unit. The submssion of recommendations must be detailed and must be preceded by notice to all local governments and regional planning commissions having jurisdiction within the proposed critical area. The Administration Commission is given forty-five days to adopt, adopt with modification, or reject the recommendations. When adopted, the rule will establish the boundaries and the specific "Principles for Guiding Development " in the critical area.

This procedure is basically followed by all states, however, the authority to designate and select such areas varies among the states. In Florida, the state Planning Agency recommends the designation of specific areas, and the Administration Commission, depending upon the governor's confirmation, designates the critical areas. Also, prior to the designation, an inventory of land owned by the state must be filed with the state land planning agency. As previously mentioned, the designation of such areas is limited to $5 \%$ of total state land area. The law also restricted critical areas designation in the first year of enactment to 500,000 acres. The purpose is to reduce the amount of land controlled by the government and to minimize 
the negative impacts of the legislation on private property rights which seems to be a proper approach in terms of reducing the probability of litigation. On the other hand this is regarded as a severe limitation on the proper protection of all critical areas in a state with invaluable resources.

\section{REGULATION OF CRITICAL AREAS}

Upon the designation of a critical area, local governments ought to submit existing and proposed regulations to the state agency for a review. If within a prescribed period (six months) the local governments fail to submit satisfactory regulations, the state may adopt and enforce its own established regulations. The land development regulations adopted by the Commission will be administered by the local governments. If, however, the Division of state Planning determines that the local goverment is failing to administer them in a manner adequate to protect the state or regional interests, the Division may institute judicial proceedings to compel the proper enforcement of the land development regulations. Upon the recommendations by the local agencies and approval by the state planning agency, these regulations may be amended. This procedure is recommended by the ALI Model Code, however, some states have different provisions and do not follow the same pattern.

The state of Florida follows the ALI Model Code to a 
great extend with some additional provisions. The state agency is capable of initiating a lawsuit if the local enforcement of the regulations seems inadequate. Also the local governments must notify the state agency of all development orders. The grant of development orders may be appealed to the Land and Water Adjudicatory Commission if not properly decided by the local government.

These extensive provisions establish definitive responsibilities and set time limitations on the decision for the approval or rejection of development regulations, and the approval or rejection of proposed amendments. They provide for the participation by the local and regional agencies at the crucial regulation-promulgating stage and at the implementation stage. The state, while having power to approve, reject, or modify local development regulations, acts throughout the process as an external stimulus and coordinator attempting to ensure reasonable, rational growth regulations that are consistent with statewide interests and concerns. The law provides, however, that if no regulations were adopted after a year, either by the local government or by the state, the designation of the critical area is to be terminated, and no additional area designation be made for another 12 months.

CONSTITUTIONAL PROVISIONS

One of the most common and frequent criticisms of any land use regulation is the possibility of infringing upon the private property rights which amounts to a "taking" of 
private property. In order to prevent this issue from reaching the courts and from being declared void and invalid, most critical areas statutes include a constitutional clause. This is usually in the form of a simple statement such as: "the law is not to be construed as enhancing or diminishing the rights of property owners under the U.S. or State Constitution".

The threshold problem with the Area of Critical State Concern provision is therefore the extend and degree to which state control and regulation is imposed upon the use and development of private property. The Florida constitution provides: "No private property shall be taken except for a public purpose and full compensation therefore paid to each owner". This language resembles that of the United States Constitution and most state constitutions. This is particularly relevant in the context of critical areas legislation. While it is commonly recognized that the state may exercise a degree of regulation of private property under its inherent palice powers, property uses may be so restricted that the regulation becomes a taking without just compensation. The Florida act does not authorize regulations or issue orders that are "unduly restrictive or constitute taking of private property without just compensation". Also the act requires the authorized agency to clearly specify reasons for denial of a development permit.

It is apparent that the states, including Florida, make some provisions in their statutes for constitutional 
issues pertaining to regulation of critical areas. However, these provisions seem inadequate with regard to the complexity of the "taking" issues. It is extremely difficult to determine "when regulation ends and taking begins". 16 For instance, the Florida supreme court has reaffirmed that the "basic constitutional right of an owner to make legitimate use of his property must not be curtailed by unreasonable restrictions under the guise of the police power". 17 The Elorida courts have consistently required that the restrictions be kept within the limits necessary for the protection of public health, safety, morals or general welfare or they will be recognized as unlawful taking. The issue, however, has traditionally been directed toward determining what are unreasonable restrictions. Thus, the degree of effectiveness of these laws is strictly dependent upon the broad consideration for property rights, an essential element of the constitution and it is necessary to evaluate critical areas legislation with a broader perspective regarding taking issues.

"courts and commentators have been unsuccessful in drawing the line between taking and reasonable regulation because of the inconsistency among the prior cases and the lack of criteria for rationally deciding the future cases". 18

The reason behind the absence of a consistent set of prior cases and established criteria to evaluate the reasonableness of a regulation lies in the nature of taking cases with various factual settings. The courts have generally utilized a case-by-case strategy and therefore 
have failed to adopt proper guidelines for future references. However, courts have taken various approaches to decide upon the reasonableness of a land use regulation. The "due process" test is commonly used to determine the existence of a rational goal for the states actions and the presence of reasonable and relevant means to the objective sought. Generally if the acts' objective is to protect the public health, safety, and general welfare, it is often recognized as a rational basis for state regulations. Also courts are permissive of a state's effort to preserve its natural resources and environmentally sensitive areas. With regard to the critical areas these two objectives seem to be identified and clarified by the statutes. In fact these acts are rather comprehensive in this aspect and encompass a variety of issues in light of public welfare and protection of natural resources and environmentally critical areas which is not only important for specific communities but concerns the state as a whole. Whether the means to achieve these goals are reasonable or not, it can be stated that, especially in the state of Florida, the provisions of the acts are consistently derived from the ALI Model Land Development Code which is regarded as a sound and adequate guideline and therefore a strong ground to evaluate the means to the end sought in this form of state regulation. Another approach is the "balancing" test which is the means to measure the public gain in relation to the private loss; "weighing of the public benefit against the burden cast upon the private property should be the controlling 
consideration in defining whether there has been an exercise 19

of eminent domain or of police power". Therefore a taking occurs when there is a substantial violation of property rights to the extent of outweighing the public benefit. Although this concept is applied differently to various cases, with respect to the regulation of critical areas and valuable land resources with a regional or statewide significance, generally the degree of public benefit is adequately high in comparison with other land use restrictions and regulation such as municipal zoning regulations. The maltreatment of critical areas, as emphasized before, does have significant negative impact upon the lives of a broader public which in many cases, certainly outweighs the individual loss of property rights.

The final approach which is more applicable to any type of land use regulation similar to critical areas regulation is "the existence of an alternative, reasonable use and the development of a comprehensive plan to which the the restriction must conform". The courts have generally upheld the restrictions if "the plans and regulations allowed alternative uses, even if very limited, or absolute but for a limited period of time".

The first criterion, the existence of the alternative uses is carefully considered in the acts by excluding from restriction certain classes of use and development that are consistent with the objectives of the acts. Secondly the acts make provisions for the approval of development by the 
local agency if it is within the established regulations. The Florida legislation, as previously discussed, authorizes the state agency to review the decisions by the local agency on development orders which provides assistance to the local bodies in assessing the impacts of development and proposing alternative uses. Finally, some states establish procedures for appeals (Florida Land and Water Adjudicatory Commission) and for amendment and modification when changes are necessary.

The second criterion, the compliance with a rational comprehensive plan is at least partially provided in the acts. This is not a requirement but it is highly considered by the implementing agencies in the establishment of the development regulations and subsequent amendments. The authorized agencies have realized that in the absence of such a plan the imposed restrictions would be almost impossible, justify in the courts on the basis of unreasonable exercise of the police power. This is one of the major reasons for the simultaneous adoption of the Florida Land and Water Management Act and the Comprehensive Planning Act of 1972 .

Florida's Areas of Critical State Concern provision appears to possess attributes of those ordinances and regulations that courts have held valid. The objective of the Florida act is not to absolutely ban growth or development but rather to establish a sound plan for a controlled, rational rate of development and land utilization within a well-defined area determined to be of a 
sensisitive nature. Certain uses, consistent with the prime objective of the act, are exempt from coverage. Detailed provisions exist both for the approval of individual developments and for modifications and changes to the development regulations. These regulations are to be administered at the local level with the local authorities having the power to approve any project permitted under the established development regulations.

Although the critical areas provision generally follows the detailed ALI Model Code, the Florida legislature has burdened the act with two provisions that may reduce its potential effectiveness. The first provision provides that between the time the rule designating a critical area is adopted and the time the final land development regulations are formulated and approved, any local agency within the proposed critical area jurisdiction may authorize any development consistent with the existing local regulations. This extensive period of time is purposely given to the regional planning agencies and local bodies to make detailed and adequate recommendations to the state for approval. However, time exists for the vesting of development rights that could have serious impacts upon the designated critical areas. The proper solution is perhaps a total freeze on the development in those areas or development moratoriums. A number of courts have approved the imposition of such moratoriums as a reasonable exercise of the police power if the freeze were for a finite period of time and had a 
reasonable public purpose.

The second provision weakening the act is the five percent cap on the amount of land to be designated as critical areas. The state of Florida has an immense and valuable zone of coastal inland wetland. This cap allows only a fraction of this wetland to be regulated under the provisions of the act. There have been suggestions as to the elemination been suggestions as to the elimination of the five percent cap or to exempt the wetlands from the cap to achieve maximum effectiveness. The lack of an interim freeze and the imposition of the five percent limit may have been two major weaknesses of the Elorida Land and Water Management Act. However, it has allowed the act to survive public and local resistance in terms of infringement upon individual property rights and increased state control. The act can serve as the initial step toward effective land use planning and when it is widely accepted as a unique strategy for growth management and environmental protection. Its inherent flexibility will allow for modifications and amendments in the future.

The case of Askew vs. Cross key Waterways in Florida addresses another constitutional issue with regard to the designation and regulation of critical areas. The controversy was initiated because of the designation of Areas of Critical State Concern by the Administration Commission of the Department of Administration. In November 1978, The statute was ruled defective because it 
in the government of land development. "Under the doctrine of nondelegation of legislative power, legislature is not free to redelegate to an administrative body so much of its lawmaking power as it may deem expedient". Both in the district court and the appelate court, the statute was declared unconstitutional because the determination of geographical areas and resources in need of protection is a task requiring the performance of a legislative body rather than an administrative body. Presumably, the courts would have upheld the statute if there was adequate proof of the administrative agencies performance in complete accordance with the legislature's intent. In this case, the legislation was deemed inadequate inadequate in providing guidelines and criteria to determine whether the agency is carrying out the objective of the legislature; "then in fact, the agency becomes the law-giver rather than administrator of the law".

Here the legislation is also defective due to the absence of set priorities among competing areas and resources in need of protection. It is important to note that if priorities are established and the legislature provides adequate directions for the implementation of its policies, there is no violation under the nondelegation doctrine. Thus, provisions must be made in establishing guidelines so that the administrative agency can properly implement the set policies and not unconstitutionaliy abuse the legislative power. 
A task force was established to recommend a legislative action, in both 1979 and 1980 sessions of the Florida legislature. The following amendments resulted in the readoption of the critical areas provision that: "(1) retained the authority for the executive branch to initiate and make critical area designation, but added an opportunity for the legislature to veto action at its next session; (2) spelled out in more detail the criteria for designation that would guide the administrative process; ( 3 ) made mandatory the use of resource planning and management study committees to attempt voluntary resolution of development problems before a formal critical area designation could be made; (4) provided that all future designations sunset three years after the adoption of acceptable land development regulations by local governments, and for even earlier dedesignation under certain circumstances; (5) established closer ties between Areas of Critical State Concerns and the Environmentally Endangered Lands Purchase Program; (6) required that all local governments in critical areas conform their comprehensive plans to the critical areas " principles for guiding development"; (7) provided that the City of Key West would be deleted from the Keys critical area designation on approval of the land use element of the City's comprehensive plan; (8) provided that the entire Keys critical areas designation would be ended July 1, 1982, subject to certain conditions being met." 
IMPLEMENTAT ION

Three major areas have been designated by the state of Elorida as Areas of Critical State Concern: the Big Cypress, the Green Swamp, and the Elorida Keys area. Four other areas were considered for designation but due to the costly and lengthy process of critical areas designation and limited staffing of the land planning agency, it was suggested that alternative management strategies would be more appropriate.

The Big Cypress Swamp is the first critical area designated by the state of Elorida. It is an uninhabited area of more than one million acres to the north and west of the Everglades National Park. It serves as an aquiferrecharge area and contains numerous ponds providing a vital source of water to the park and its unique wildlife habitat. Growth pressures and private land speculation in this area led to the involvement of both federal and state governments in some form of growth management for the protection of these resources. By late 1978, approximately half of the area was purchased by the federal government. Despite this major contribution, there still remained an abundant quantity of unprotected land. Finally the Big Cypress Swamp area was designated by a special act of the legislature as a critical area. This special act not only quickened the designation process but also disregarded the five percent acreage limit in light of complete portection of this resource area. The critical area 
regulation appears to be effective in the Big Cypress Swamp area; many major developments have been turned down due to the failure to conform with the state guidelines. This certainly illustrates the positive role of state regulation in growth management and the local acceptance of state interference when regulation follows justified and proper designation of a critical area. The implementation process as well as the designation process is confirmed to be effective in the Big Cypress swamp area. The political climate in Collier county, favorable to growth management and enforcement of state regulations along with the participation of competent professional staff has brought success to the process of critical area program implementation in that environmentally sensitive area environmentaliy sensitive area.

The Green Swamp area $(800,000$ acres), containing major wetlands in half of its area, was the second critical area in the state. Growth pressures threatened this area mainly after the establishment of Disney World in its close proximity. In 1974, the governor and the cabinet, after review of the state planning report on the environmental resources of the area, designated 323,000 acres of the Green Swamp (with the $5 \%$ cap) as a critical area.

The legislative crisis of 1978 and the court ruling that held both the keys and the Green Swamp Areas of Critical State Concern designations unconstitutional, required a reassessment of the designation process. the 1979 
special legislative session redesignated the Green Swamp but the action provided for a lifting of the designation if and 28

when three conditions were met: (1) Approval by the state land planning agency of the local land and development regulations (2) Such regulations being effective for a period of 12 months. (3) Adoption or modification of the local government comprehensive plan to confirm to the "principles for guiding development" for the Elorida Keys Areas of Critical State Concern.

A committee for the Green Swamp was established in September 1981 charged with the responsibility of reviewing land development regulations of Polk and Lake counties to determine whether they meet the requirements for repeal of the critical area designation. While the Green Swamp Committee was assisting the two counties in developing and gaining approval for their own regulations, the Department of Community Affairs report in June 1982 to the governor and the cabinet sitting as the Administrative Commission concluded that the Green Swamp area was not elegible for dedesignation. The local governments had failed to adopt regulations to conform to the critical areas "principles for guiding development". This resulted in a more direct involvement of the state land planning agency in the implementation of the program in that area because local and county governments were clearly unable to enforce the existing standards.

The Florida Keys area designation was of different nature since the keys were already partially urbanized and 
there was great support from the local residents who expressed their concerns through a local environmental movement. The Keys were suffering from the negative impact of tourist and residential growth not only upon the environment but on the public services as well. The failure of the local government to protect a resource area of statewide and nationwide importance resulted in the need for serious state intervention. The whole island chain, including the only large town, Key West, was designated as a critical area. The local governments were subject to plans and zoning maps prepared for the protection of natural resources and to an increase in the cost-effectiveness of public investments. Also, the developers were required to prepare a "Community Impact Assessment Statement" along with their proposal of large and medium-sized projects.

The designation of the Florida Keys Area was in place. However, the local governments in the Keys -Monroe County and four municipalities-missed the six months deadine requiring that the Administrative Commission formally adopt the land development regulations. At this time the city of Key West was removed from the critical areas designation by action of the 1979 legilative session effective July 1, 1981.

Similar to the Green Swamp area, the Keys area was nominated to be lifted from designation. The Florida Keys Resource planning and Management Committee and the Technical Advisory Committee findings rejected the dedesignation which 
was confirmed and approved by the Administration Commission in June 1982 .

Various studies have been prepared to evaluate the critical areas implementation in the Keys. These studies all emphasized the need to strengthen the monitoring and enforcement of critical areas standards by the state land planning agency.

"The sum and substance of these studies present a sad and sorry litany of insufficiently specific standards and guidelines; an inability of an understaffed and sometimes unqualified planning were in place; and a failure of either the zoning board or the county commission to take seriously the enforcement of standards, often ignoring good staff work where it existed". 29

Therefore, due to lack of proper state guidelines and standards and deficiencies in local government implementation strategies and techniques, the critical areas program was not very effective in managing the growth in the Keys and preserving its resources. The blame was equaly shared by the state who had never initiated an appeal of the local governments decision until 1982. "Development orders, major or otherwise, were approved by local governments and allowed to stand by the state that did not meet the "principles for guiding development. With the exception of one development order involving the Key West Historical District, no development order until 1982 had ever been appealed by the state land planning agency".

The above description of the critical areas program in Florida clearly demonstrates the inadequacies and defficiencies of local administrative machinery in dealing 
with land use issues that concern the entire state, and the need for state intervention or oversight in ensuring the protection of resources with a statewide significance. The state, however, should be equipped for a strict monitoring process in terms of budget, professional staff, and adequate and precise guidelines. In other words, a state-local collaboration and division of tasks and related responsibilities is crucial to the effectiveness of the program.

The Florida critical areas program has been a fairly successful and effective tool to achieve the state's objective of controlling major environmentally sensitive areas. However, the state has been reluctant to designate additional critical areas.

The critics point to various reasons for this program's stagnation. Many criticize the leadership of the division of State planning for its political timidness; many perceive the delay in the completion of the state comprehensive plan which was not completed until 1978 as the downfall of the program; they believe that the lack of direction in the first months after the adoption of the program was a major obstacle. "By the late $1980^{\circ} \mathrm{s}$, when all local governments are expected to have completed their plans and regulations, a major loophole in the Land Management Act of 1972 will be closed".

Another major criticism has been the procedural difficulties of the program. The pressure of statutory time 


\begin{abstract}
deadines along with the state burden of furnishing exact information in the process has led the state planners to attempt to achieve similar results without formally deisgnating any critical areas. In lieu of area designation, the state has helped the establishment of a thirty-one member committee consisting of representatives of state agencies, regional planning councils, county governments, businesses, and conservation groups. The committee's main objective is to assist the local bodies in making better land use decisions. It appears that the state is reluctant to designate critical areas and to invest time and money in this complicated process except when the growth problems have reached the ultimate difficult stage and when other remedies have been truly exhausted.
\end{abstract}


DEVELOPMENTS OE REGIONAL IMPACT (DRI)

The provision of the ALI Model Land Development Code for large-scale developments or Developemnts of Regional Impact (DRI) was specifically appropriate in Florida as so many recent developments were large in size and far-reaching in effect. The Florida law of 1972 classifies developments affecting more than one county as Developments of Regional Impact. In 1973, the following developments were designated DRIs :

1) an airport;

2) a race track or sport stadium;

3 ) power plants larger than 100 megawatts;

4) high voltage electrical transmission lines with cross county boundaries;

5 ) hospitals serving more than one county;

6) manufacturing plants or industrial parks with parking for more than 1500 cars;

7) mining activities disturbing more than 100 acres annually:

8) large port facilities or oil storage tank;

9) a post-secondary educational campus of more than 3000 students;

10) a shopping center with more than 49 acres or providing more than 2500 parking spaces;

11) housing developments, mobile homes park or subdivisions larger than 250 units in low population counties or larger than 3000 units in populous counties.

Unlike critical areas designation, the DRI decisions involve state reaction rather than initiative. The DRI process starts with the developer's proposal for a largescale project to the local government. The process also requires the involvement of a regional planning council, the state planning agency (Division of State Planning), the Administration Commission, and the State Land and Water Adjucatory Commission. 
The developer has to submit an application or in essence an environmental impact statement of his proposed project to the local government and to the appropriate regional planning agency. This agency, within fifty days of the application submission, proposes recommendations on the regional impact of the proposal. The statute requires that the regional agency consider whether:

a) The development will have a favorable or unfavorable impact on the environmental and natural resources of the region;

b) The development will have a favorable or unfavorable impact on the economy of the region;

c) The development will efficiently use or unduly burden water, sewer, solid waste disposal, or other necessary facilities;

d) The development will efficiently use or unduly burden public transportation facilities;

e) The development will favorably or adversely effect the ability of people to find adequate housing reasonably accessible to their places of employment; and

f) The development complies with such other criteria for determining regional impact as the regional planning agency shall deem as appropriate, including but not limited to, the extend to which the development would create an additional demand for or additional use of energy, provided such criteria and related policies had been adopted by the regional planning council.

With or without consideration of these recommendations, the local government may give approval or issue the development order. However, the $s$ tute requires the regional overview. In considering the findings of the regional agency which usually encompass environmental as well as socio-economic factors, local governments are further mandated to consider whether: 
a) The development unreasonably interferes with the achievement of the objectives of an adopted state Land Development Plan;

b) the development is consistent with the local land development regulation; and

c) the development is consistent with the report and recommendations of the regional planning agency.

It is at this point that the state involvement and control begins. If the Division of State Planning or the regional planning agency disapproves the local governments decision, they may appeal to the Adjucatory Commission which is required to give a decision within 120 days. Also, the developer may appeal upon the denial of his project proposal by the local government. The Adjucatory Commission either denies permission to develop under the order, or grants permission to develop, but with additional conditions and restrictions. Such actions by the Adjucatory Commission are subject to judicial review.

It is very important to note that the DRI process, as described above, is only applicable to communities that have zoning or subdivision regulations. Otherwise, a developer is required to notify the state planning agency and the local government of the intention to build a project. If within 90 days the DRI or critical area regulations were not adopted, the developer can well proceed with the project without regard to chapter 380 . This emphasizes the importance of the Comprehensive Planning Act which would rectify this major weakness of the legislation. 
In general, Florida DRI process is a combination of local control, regional evaluation and state overview. The state, however, is not as directly involved in the DRI process as in the critical areas designation process. Also, the burden of proof is on the developer which includes the collection of site-specific information and the determination of impact upon the locality and the region.

As to the effectiveness of the DRI process, a statistical review from 1973 to 1982 reveals some useful 36

information. BY June 30, 1982, a total of 380 applications involving developments of regional impact were filed throughout the state of Florida. By June $1981,55 \%$ of these projects were residential projects, involving proposals for more than 1 million housing units, most to be completed by the year 2000. The other major categories were shopping centers ( $11 \%)$, phosphite mining projects (5\%), major electrical transmission lines $(4 \%)$, office parks $(6 \%)$, amusement and recreational attractions $(4 \%)$, ports $(5 \%)$, petroleum storage $(3 \%), \operatorname{school}(1 \%), \operatorname{airports}(3 \%)$, industrial plants $(2 \%)$, and finally hospitals $(0.3 \%)$.

Detailed analysis, summarized in Table 2.1 indicate that there was a drastic decline in the number of DRI projects in each year of implementation until 1977-1978: 
Table 2.1

\section{..........}

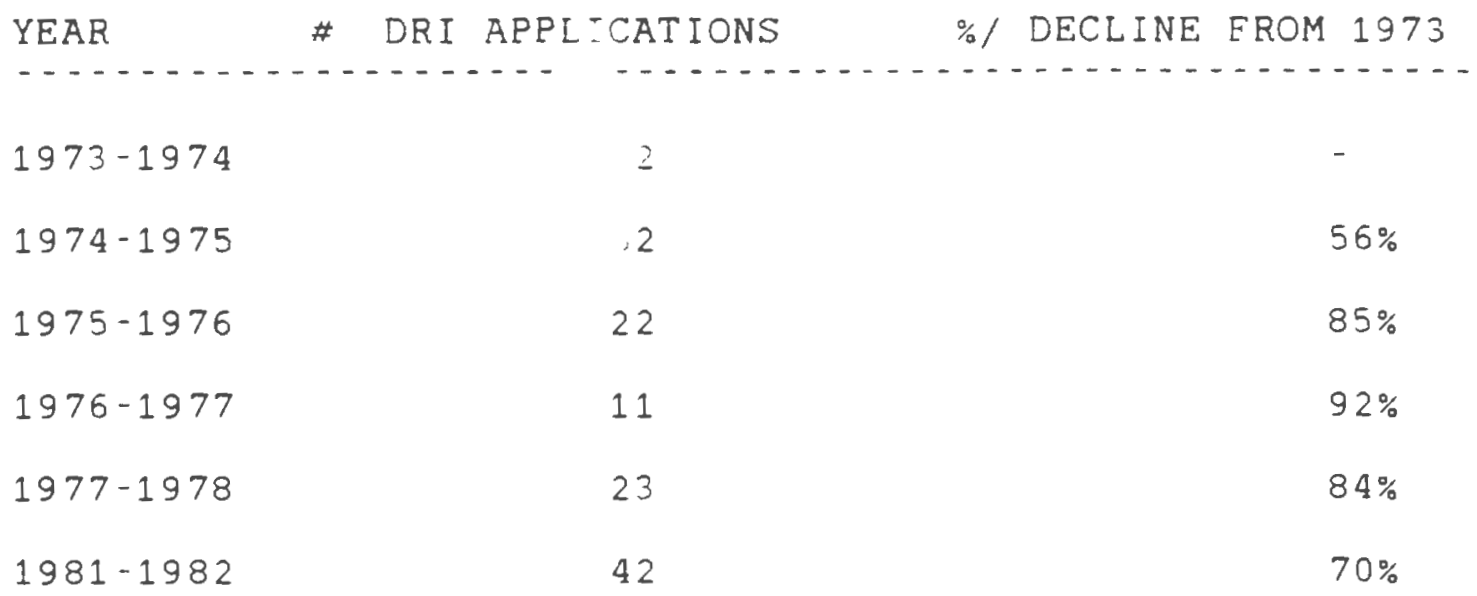

The reason for the abnormally large number of DRIs in the first year was the concur ancs of the DRI process with the most explosive constructi. $t$ ms of the Florida state. The decrease in the number of EI plications can therefore be attributable tc the decline in the construction industry as well as the mere existence of a somehow stringent state program.

Another i.eresting observation is made from data relative to appro l/denial of the DRI applications. Of the 243 DRI applicati s acted upon between the years 1973-1981, $9 \%$ were approved, ithout conditions, $7 \%$ were subjected to outright denial, L.t most ( $84 \%$ ) were conditionally approved.

The practice of attachi g conditions to DRI approvals increased the need for an effective monitoring process without which there would be no assurance as to proper implementation. However, conditional approval was proven to be very effective in the elimination of problems caused by 
the projects initial design. This also suggests that the DRI process possesses a flexibility and potential for a higher level of communication and private-public negotiations which are the key to the effectiveness of such a program. Thus, while a large number of conditional approvals points to a sound, more flexible and consequently a more acceptable program, it seriously suggests a careful consideration for a proper monitoring process and enforcement at the state level. Similar to the critical area program, the existence of a competent professional staff and adequate state guidelines and assistance to the local governments would ease the DRI process.

Another measure of an effective DRI implementation process is the number and result of appeals. From 1973-1981, 46 development orders were appealed. As of $1981,50 \%$ of appeals were initiated by the regional planning agency, $25 \%$ by the state and $18 \%$ by developers. In just over half (24) of the 46 appeals, a negotiated settlement was reached when the Adjudicatory Commission dismissed the appeal but approved an amended development order. In 5 cases, the court rejected the appeals by adjacent counties on the basis of lack of standing. By 1982, all efforts to amend chapter 380 and broaden standing by including adjacent local governments, individual citizens or other interested groups had been rejected. This would have brought the Florida Law into line the ALI Model Code liberal standing provisions. This points to a major shortcoming of the DRI process which is the limited involvement of individual citizens and the 
lack of community participation in the negotiations between the developers and the governmental agencies.

Another major issue is the developers protest against the lengthy and aggravating process of providing information and responding to the constant demand of various decisionmaking bodies. Additionally, the regional coloring of land use planning is a novel concept with inherent weaknesses and inadequacies. Regional planning is perhaps the best means to systematically evaluate complex metropolitan areas and to allocate land uses in a most equitable manner. However, "for regional planning to be effective, it must be linked with the regulatory authority; planning and control should be exercised at the same scale". 37

The DRI process requires the involvement of the regional planning bodies at the planning level, in terms of evaluating the developers 'proposal and assisting the local governments by proposing recommendations. However, the regional agencies have no regulatory authority by which to enforce and implement the regional plan.

The 1980 Florida Regional Planning Council Act was a major step towards strengthening the position of the regional councils. Until 1980, one of the problems with the regional assessments was the membership of regional planning councils which was consisted entirely of city and county elected officials. The $1980 \mathrm{R}$-ional Planning Act required that the membership of the rejic $x$ l councils be composed of 
one third members appointed by the governor.

SUMMARY

The state of Elorida has taken an alternative approach to state land use planning and control, in response to its two major problems: rapid urbanization and its negative impact upon the fragile and unique environment, and the effect of large-scale developments on the state resources.

In 1972, based upon the ALI Model Land Development Code, the Florida Environmental Land and Water Management Act was passed. The law required the state designation of Areas of Critical State Concern ( $A C S C$ ), and the state regulation of Developments of Regional Impact (DRI). This was a state-local collaboration in land use decision-making designed to effectively improve the land use decisions at the local level by state provision of information, principles and guidelines.

With regard to the critical areas program, only three areas have been designated by the state: the Big Cypress, the Green Swamp, and the Florida Keys areas. There has not been any additional area designation mainly due to the difficulty in meeting procedural requirements and consequently, difficulty in program implementation. The process is lengthy, costly and requires exact information and data which might be difficult to obtain. Therefore, the state has been reluctant to proceed with further area designations and has selected growth management strategies 
to achieve similar results. However, the program is highly valuable when environmental quality is threatened by massive and unmanageable growth and short-term remedies do not effectively resolve the problem.

The regulation of Developments of Regional Impact has been more successful in the state due to less direct state involvement, less local resistence, and a more flexible review process. Here, the developer has the burden of proof and is required to qualify under the state and regional principles. This novel concept of regional impact assessment by the private developer not only is difficult to implement but may discourage the developers from investing in a community. Also, the lack of citizen participation in the land use decisions has always been a shortcoming of this programs.

The Florida legislation is established based upon the ALI Model Land Development Code and it is structured with a similar statutory language and administrative pattern. However, due to the generic and encompassing nature of ALI's principles, the Florida provisions are modified to meet the needs of the state. Table 2.2 demonstrates the differences and similarities between the ALI Model Code guidelines and the Elorida act provisions: 
AL I MODEL CODE

$$
\text { .............. - }
$$

Definition

State-Local Relationship

Adminstrative Structure
- Broad definition, 4 major categories

- Local implementation of state policies

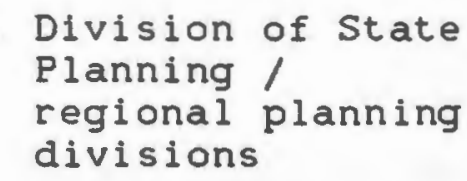

- Local land development agencies

- state and regional advisory commissions

- Land development Adjudicatory Board (Professionals also)
FLORIDA LEGISLATION

-..................

- Broad definition, 3 categories

- Local implementation of state regulations

- State planning agency (governor $\&$ (abinet) or Administration Commission

- grRegional planning agencies

- Environmental Land Management Study Committee

- Land and Water Adjudicatory Comm. or Administration Commission

Designation
- Division of State Planning, any regional planning agency or a local gov. unit recommends areas
- state planning agency designates boundaries (statement of reasons)

state agency recommends areas - Inventory of 1 and owned by the state

Adminis . Comm. designates Legislative Veto Power (1980 Amendment)

- principles for guiding . development must be establ ished

Local Comprehensive Plans must conform with guidelines (1980 Amend)

- Notice to affected local governments

- $100 \%$ coverage
- Same as ALI

- 5\% of total state area 
Regulation

- upon designation, same as ALI local governments have six months to submit regulations

- Designation suspends local governemnts to grant development permits to extend specified

- No moratoriums or interim controls

- failure to submit will. same as ALI Code result in state adoption and enforcement of its own regulations

. when adopted, will be administered by local government

- failure to properly failure to properly administer will result enforce regulations in judicial proceeding initiated by state planning Agency

same as ALI Code can result in a law suit by the state planning agency

- local governments must notify the state agency of development orders

Constitutional. provision

Article 6 compensation for development regulation
- Act does not authorize govern. agencies to adopt regulations or issue orders that are unduly restrictive or constitute taking of private property without just compensation

- Act requires reasons for denial of a development permit 
The Elorida act has been critized for two provisions that may reduce its effectiveness in terms of proper protection of state resources. First is the $5 \%$ cap on the amount of land that can be designated as critical areas, and second is the lack of interim control between the time of area designation and the time of regulations approval and adoption. It should be noted that despite the negative impact of the $5 \%$ limit, it may be regarded as a measure to reduce the amount of local resistence against too much state control and to eliminate litigation as much as possible. Interim control, however, appears to be a valid recommendation in terms of resource protection to the full extend: development moratoriums are able to effectively resolve this issue.

Despite the shortcomings and inadequacies of Florida legislation, it is a point of departure for many future actions in state regulations and protection of valuable resources. It provides a strong basis for planning at the local level and a means for coordination and cooperation among variaus levels of government involved in the land use decision-making process. The law is not the ultimate solution but perhaps the best starting point. "Beyond the considerable task of implementation, the new Iaw has given Elorida a heightened awareness of all that remains to be done". 
1. Jackson, Richard H., LAND USE IN AMERICA, 1981, p.84

2. Degrove, John M., LAND, GROWTH, AND POLITICS, 1984, P.102

3. Ibid.

4. Ibid.

5. Healy, op. cit., p.129

6. Ibid.

7. Degrove, op. cit., p.103

8. Ibid.,pp.103-109

9. Ibid., p.110

10. Ibid., P.109

11. Ibid., p.117

12. The Council of State Governments, Issues and Recommendations, STATE CRITICAL AREAS PROGRAMS, land use Policy and Program Analysis No 5, 1975, pp.57

13. Ibid., p.58

14. Elorida Environmental Land and Water Management Act, Ela. Statutes, 1972, Chapter 380, Sections 380.05

15. Ibid.

16. Cronin, Philip M., and Fieldsteel, John $W$., WHEN DOES ENVIRONMENTAL REGULATION OF PRIVATE PROPERTY BECOME A TAKING AND REQUIRE COMPENSATION, 1985, Mass. Law Review. 72

17. Sleeth, Tim E., AREAS OF CRITICAL STATE CONCERN: ITS POTENTIAL FOR EEFECTIVE REGULATION, 1974, 26 U.Fla. Law. Review. 862

18. Binder, Denis, TAKING VERSUS REASONABLE REGULATION: A REAPPRAISAL OF REGIONAL PLANNING, AND WETLANDS, 1972,25 U.Fla. Law Review. 1

19. Ibid. 
20. Sleeth, op. cit. p.858

21. Ibid., p.867

22. Ibid., p.858

23. Askew vs. Cross Key Waterways, 1978, Fla, 372 So.2d 913

24. West's F.S.A. Constitution., Article 2, Section 3

25. Askew vs. Cross key Waterways, op. cit.

26. Degrove, op. cit., p.127

27. Ibid., p.137

28. Ibid.

29. Ibid., p.148

30. Ibid., p.149

31. Ibid., p.129

32. Healy, op. cit., p.144

33. Degrove, op. cit.,p.119

34. Ibid.

35. Ibid., p.120

36. Ibid.,pp.154-155

37. Longsbury, John F., Sommers, lawrence M., and Fernald, Edward A., LAND USE, A SPATIAL APPROACH, 1982, p.142

38. Degrove, op. cit., p.142

39. Myers, Phyllis, SLOW START IN PARADISE, 1974, p.35 
Chapter II

THE RHODE ISLAND

CRITICAL AREAS PROGRAM

Similar to the state of Florida, Rhode Island critical area program was introduced as a major component of the land management legislation first proposed in 1974. The state-local conflict was the most prevalent issue in the adoption of such a program. The reassertion of preexisting state controls in land management programs has resulted in many controversies between the state and local governments. In general, local governments have been opposed to this greater exercise of state power in land use decisions because of the lack of citizen involvement and participation, lack of local input and the high level of bureaucracy at the state level. In Rhode Island, this conflict seems to be even more extreme and forms the basis for a resentment and distrust of the state government in land use management. Apart from the above reasons, the Rhode Island municipalities contended that the state's regulatory approach had proved defective in terms of proper assessment of impacts upon the localities. This resentment surfaced as a unified force against the land management bill which was viewed as a means of taking away local control and authority in land use decision-making.

In order to better evaluate the Rhode Island critical area program and to understand the reasons behind the state's objection to the land management bill in general, and furthermore to determine the inadequacies and 
shortcomings of the critical area program, similar to chapter II, the proposed definition, the administrative structure, designation, and regulation of areas of critical concern in Rhode Island will be examined.

FORM OF STATE-LOCAL RELATIONSHIP

As previously mentioned, the ALI Model Land Development Code delegates full responsibility for state policy administration to the local governments. Rhode Island, similar to Florida, follows the same pattern where policies are set at the state level and are implemented at the local level. Based upon a community guide plan, in conformance with the state policies, and the designation of critical areas, the local governments must develop ordinances for the areas and submit them to the state planning agency for review. The agency has an advisory role in case of inconsistencies in the proposed regulations. If a local government refuses to modify the regulations to the best interest of the community and the state, the state may appeal to the state land appeals board. The local government is then given 180 days to make corrections. If none were made, regulations prepared by the board or the state planning agency would be adopted. If the community fails to prepare regulations for a designated critical area within 6 months, the state planning agency, the property owner, any other other state or local agency, or a group of fifty qualified voters may appeal to the land appeals board which may then recommend appropriate solutions. It is important to 
note that the state-local relationship, even among states that follow the ALI Model Code recommendations, varies tremendously depending upon the political climate and the governmental tradition of the particular state and the local goverments. Nevertheless, the importance of maintaining a sound and healthy relationship is a key factor in the proper implementation and the effectiveness of the critical areas program. This program calls for a state-local collaboration in all stages, from the nomination to the regulation of critical areas and in theory, the role of the state and the local governments is complementary in the process of protecting valuable areas which directly affect a broader public.

\section{ADMINISTRATIVE STRUCTURE}

The ALI Model Land Development Code proposes the establishment of a state planning agency in the governor's office for the administration of certain land development regulations. The establishment of regional planning offices is also recommended in larger states for better control over large land areas. To review state plans and reports, the ALI Model Code recommends the assistance of a state and/or regional advisory commission(s) appointed by the governor. For appeals on land use decisions, the code calls for the establishment of a state land adjudicatory board.

Unlike the Florida act, the Rhode Island legislation does not call for the establishment of any specific agency, however, a similar one already exists. The statewide 
Planning Program consists of the Statewide Planning Council, appointed by the governor, the council's technical committes and the Council's staff, the office of State Planning. The State Planning Office is a division of the State Office of Administration, made statutory by a 1978 Act. The State Planning Council's major responsibility is to guide the State's Planning Program. Thus the Council would have an -active role in the designation of critical areas. The proposed Rhode Island legislation, however, requires the establishment of the state land appeals board as an independent decision-making boby. The board would consist of five regular members and two alternatives appointed by the governor and the senate. Furthermore, two additional voting members can be appointed by the town or the city whose ordinance is being appealed.

DEEINITION OF CRITICAL AREAS

The previous chapter revealed that the key to any land management program is the proper designation of areas of critical concern. this concept may apply to a wide range of physical, economic, and social conditions. However, a common characteristic is the designation of areas with significance extending beyond the local jurisdiction. Therefore, prior to the process of designation, a distinct definition of critical areas is crucial to the effectiveness of the program. This definition must ensure the inclusion of all significant matters that exceed local interest. A selection criteria must be established by different levels 


of government which may be broad or very explicit.
Due to the difficulty in formulating specific
characteristics and the encompassing nature of critical
areas, the Model Land development code of the American
Law Institute (ALI) has established three
general categories:

a) Districts of critical state concern:

This classification refers to districts which, because of their value as natural areas or as important cultural or historical sites, are especially sensitive to deterioration due to unwise development.

b) Developments of state or regional benefit:

the classification includes those developments, usually public in nature, which offer substantial benefits to all the citizens of the state, or at least to the citizens of an area greater than the municipality in which it is located. This would include airports, public utilities, and water supply reservoirs.

c) Large scale developments:

This classification is difficult to define. It can include any industrial, commercial, or residential development which is of such magnitude that it affects a land area larger than the jurisdiction of the local community. The impact can be defined in terms of traffic congestion, air pollution, greater need for public services and housing, or impetus to the ecenomic development of a region. Large scale developments could be defined in terms of total land area of the project, total number of proposed housing units, and the like.

The above categories are all considered areas of critical concern, however only the first is specifically a critical area. The Model Code defines critical areas as: 
a) An area siginficantly affected by, or having a a significant effect upon, an existing or proposed major public facility or other area of major public investment;

b) An area containing or having a significant impact upon historical, natural or environmental resources of regional or statewide importance; or

c) A proposed site of a new community designated in a state land development plan, together with a reasonable amount of surrounding land.

d) Any land within the jurisdiction of a local government that, at any time more than ( 3 years) after the effective date of this Code, has no development ordinance in effect.

Rhode Island defined critical areas on the basis of physical conditions which may be related to economic and social conditions of the state and the municipalities. The definition is more specific in terms of what may be considered a critical area in the particular state, However, it is encompassing as to allow for a wide range of interpretations. The proposed Rhode Island legislation defines critical areas as:

1 ) an area significantly affected by or affecting an exisiting or proposed major public facility or other major public investment or interest including:
a) highway interchanges on controlled access and limited access highways in non-urban areas...
b) airports owned and operated by the state and land areas... that obstruct the ... spaces necessary for the safe passage of aircraft...
c) public water supply sources...
d) commuter rail stations... 
2) an area containing or having significant impact upon a cultural resource of statewide importance, including historic sites, buildings, structures, or districts...

3) an area containing or having a significant impact upon natural resources including:

a) unusually fragile lands...

b) natural hazards lands...

4) an area of major economic development or development potential...

5) land within a city or town that, at anytime more than three years after the effective date of this act, has no land management ordinance in effect...

Following the guidelines established by the ALI Model Land Development Code, Rhode Island's legislative definition seems to be specific enough to encompass all areas of critical concern and broad enough to provide flexibility to confront the changing issues of communities.

The following table compares the critical areas identified by the proposed Rhode Island legislation to the critical areas generally identified in state programs and legislation:

\section{TABLE 3.1}

4 OTHER STATE PROGRAMS

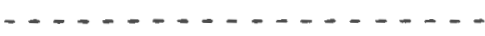

Agricultural Land

- Airports, approach zones noise impact areas

- Areas above a stated altitude

- Areas subject to frequent weather diasters

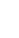

(1)

\section{TABLE $3 . . . . .$.}


- Coastlines, coastal areas and $t$ idewater

- Communication facilities, transmission lines, R.O.W

- Ecological Communites

- Educational or research areas, ethnic colonies

- Elood Hazard areas

- Highway interchanges at a limited access route - Historic sites with architectural or archeological significance

- Low or moderate housing areas

- Mass transit terminals/ systems

- Mineral extraction sites

- Unique natural areas

- New communities, sites and adjoining areas

Port facilities

- Power plant /other energy production facilities sites

- Prime sites for economic development and jobs

- public facilities supporting development

- Restricted population zones

- Rights of way/means of access to water

- Rock outcrops/shallow bedrock

- Scenic vistas

- Seismic or volcanic activity areas

- Steep slopes

- Unusually fragile lands including shorelines of lakes, ponds and streams

- Rare or valuable ecosystems, biological features and geological formations

- Natural hazard Lands including floodplains and steep slopes

- Highway intersections

- Historical sites, buildings, structures

- Historical and archeological landmark districts

- Commuter rail stations and surrounding land

generally covered

- Areas of major economic development or development potential of at least 100 acres

covered in natural hazards land 
- Unsuitable Soils for construction and on-site sewage disposal

- Solid waste disposal areas

- Storm protection facilities/ natural features

- Urban fringe areas subject to rapid growth

- Sources of water supply

- Wet lands

- Wildlife habitats
- Aquifer recharge areas

- Wildife habitats including habitats of rare and endangered species classes 1,2 , and 3

- Land within a city or town that at any time more than 3 years after the effective date of this act has no land management ordinance in effect, until such time as the city or town adopts a land management ordinance

- Renewable resource lands where development could result in loss or reduction of continued long rang productivty endangering water, food, fiber, or forest resources

Table 3.1 reveals the omissions by the Rhode Island proposed legislation. Coastal areas including coastlines, tidewater, and salt marshes, fresh water wetlands, public facility sites, developments of regional impact and other classes of land are not designated as areas of critical state concern. The omission of coastal areas and wetlands is due to the existence of the Coastal Resources Management Act and the Fresh Water Wetlands Act which are adequate measures to protect these extremely valuable and fragile natural resources. Therefore, the critical areas 
legislation, if approved, would complete a legislative package that protects all valuable resources of the state against massive, uncontrolled growth, and unwise development. There are other technical or political reasons for not including certain areas in the list of potential critical areas. For instance, the omission of public facility sites, developments of regional impact, solid waste disposal areas, or others. may be attributed to the uncertainty about the exact location of these facilities or potential state-local controversies in identifying these areas specifically.

DESIGNATION OE CRITICAL AREAS

The broad, yet clear definition of critical areas is the most important legislative guideline by which the administrative agency may actually designate certain areas as critical. However, a more significant factor in proper designation is the planning process by which these areas are determined. For instance it has been suggested that a three step process should be applied:

"First those natural areas of the state experiencing the greatest threat of destruction should be established. Second, a statewide evaluation should be made to examine resource base, in certain areas, the direction of development patterns, and the adequacy of existing controls. Finally, the municipal boundary lines should be examined to determine what types of critical areas transcend several boundaries, or where the benefits or burdens of critical areas are extraterritorial to the municipality." 6

Therefore, an effective planning process requires a comprehensive study of the state's natural and man-made 
resources, the growth trends, and the direction of future development. This will enable the state to make a comprehensive designation of critical areas. The designation process in the proposed Rhode Island legislation starts with the recommendation of critical areas by "the division of state planning or any other state agency, any member of the general assembly, a city or town council or any group of fifty qualified voters". This is very different from the Florida provision which limits the standing to the land planning agency. The recommendation must specify boundaries, reasons why the area is considered critical, state the negative consequences of uncontrolled development, and finally propose a prefered type of development along with proper guidelines.

The state Planning Council is required to review the recommendations, consult with the town or city within which the recommended area is located, and where a public hearing is to be held. When the council reaches an agreement on the significance of the area, it forwards its recommendations to both houses of the state legislature. Upon the approval of both houses, the critical area designation process is finalized. It is very important to point this major difference between the Rhode IsIand and the Florida programs in terms of final approval. The Florida act delegates the power of designating a critical area to an administrative body, the land planning agency, with a legislative veto power on the decision. 
REGULATION OE CRITICAL AREAS

Upon the designation of critical areas, the local government is required to submit new regulations if existing regulations are not adequate. A public hearing is to be held before such regulations are submitted to the state Planning Council for a review. The council does not have the authority to reject the proposed regulations. However, it is required to notify the local government of any inconsistencies with the state guidelines. The local government may adopt regulations after the public hearing and the state review. The critical areas regulations will be also administered and enforced at the local level. If the adopted local regulations were found to be inadequate and incapable of protecting the valuable resources of the area, the Council may appeal to the land appeals board. The board may recommend changes to improve the regulations. The failure of local government to amend the regulations in 180 days may result to new regulations imposed by the appeals board or state planning agency.

The local community is required to notify the state of any development order in a critical area. If the local government failed to do so, the council could bring the matter to the appeals board. Also, development permits may be granted in the critical area if the development is proven to be essential to the public health, safety and welfare. 
CONSTITUTIONAL PROVISIONS

The proposed Rhode Island legislation was designed to minimize potential for litigation by allowing the participation and serious involvement of all interested parties and the public at large in both the designation and regulation process. The land appeals board would be established to protect the rights of the property owners who believe that the critical area regulations constitute a taking of their property without just compensation. The appeals process would be established to guarantee equal protection for the landowners, and provide for both administrative and judicial review. The property owner may seek amendments of the regulations through the land appeals board. If the request is not acted upon in a satisfactory manner, the owner can present the case to the Rhode IsIand Superior Court and the Rhode Island Supreme Court.

As specificaliy discussed in the previous chapter, The compensation issue and assessing the reasonableness of land use regulations has been a difficult problem to resolve in deciding the land use cases in the courts and in evaluating a new land use program. Generally, states make provisions in their statutes and include a constitutional clause.

Article 6 of the ALI Model Code deals with the compensation issue: "the constitutional requirement of just compensation is generaliy interpreted as requiring governmental agencies to offer cash or its equivalent at the 
time real estate is acquired...it also permits the agency and the seller to negotiate in terms of periodic monthly payments, issuance of bonds, or the purchase of annuity 8 contracts.

The Rhode Island proposed legislation does not include a constitutional clause, nor does refer to the compensation issue. This may be a major shortcoming of the proposed legislation. Although such a simple constitutional clause may seem inadequate with regard to the complexity of the "taking" issue in land use regulation, nevertheless, its inclusion is absolutely necessary and important.

SUMMARY

The proposed Rhode Island critical areas legislation as a component of the Rhode Island land management bill was formed on the basis of the American Law Istitute (ALI) Model Land Development Code. Table 3.2 demonstrates the similarities and the differences between the Rhode Island legislation and the ALI Model Code.

\section{TABLE 3.2}

\section{-........}

ALI MODEL CODE $\ldots \ldots . . . . . . . .$.

Definition . Broad Definition, 4 major categories
RI PROVISION -...........

specific definition, 5 categories including areas of major economic potential and sub-categories 
State-Local. Local implementation Relationship of state policies

Administ . Structure

\author{
Structure
}

.

Local implementation
of state policies
Division of State Planning

- Regional planning divisions

- State and regional advisory commissions

- Land development adjucaditory board (Professionals also)
- Local implementation of state approved regulations

- Already existing State Planning Council

- None required

- None required

State land appeals board (required)

\author{
Designation. Division of State Division of State \\ Planning, any regional Planning, general \\ planning agency or a assembly, city or \\ local governm. unit town, or 50 voters \\ recommends areas recommends \\ - Administration \\ Commission reviews \\ - State Planning \\ Council reviews \\ - State planning agency both Houses of state \\ designates boundaries legislature designates \\ (statement of reasons)
Regulation . Local goverments have. Same as ALI 6 months to submit regulations
- Moratoriums to extend. None provided specified
- Failure to submit . Same as ALI results in state State cannot adoption and enforcement of its regulations reject regulations but failure to sub- mit will result in regulations imposed by the appeals board or State Planning Council
- When adopted, will . Same as ALI
be administered by local government




\begin{tabular}{|c|c|c|}
\hline & ALI MODEL CODE & RI PROVISION \\
\hline & $\begin{array}{l}\text { Failure to properly } \\
\text { administer will result } \\
\text { in Judicial proceeding } \\
\text { initiated by state } \\
\text { planning agency }\end{array}$ & $\begin{array}{l}\text { - Eailure of local } \\
\text { goverments to amend } \\
\text { inproper regulations } \\
\text { in } 180 \text { days will } \\
\text { result in new } \\
\text { regulations } \\
\text { Local community must } \\
\text { notify state of all } \\
\text { development orders } \\
\text { development permits } \\
\text { only granted if } \\
\text { development is } \\
\text { essential to public } \\
\text { health, safety and } \\
\text { welfare }\end{array}$ \\
\hline $\begin{array}{l}\text { Constitut. } \\
\text { Provision }\end{array}$ & $\begin{array}{l}\text { Article } 6 \\
\text { compensation } \\
\text { for development } \\
\text { regulation }\end{array}$ & $\begin{array}{l}\text { public participa- } \\
\text { tion in both } \\
\text { designation and } \\
\text { regulation process } \\
\text { administrative and } \\
\text { juducial review } \\
\text { no constitutional } \\
\text { clause }\end{array}$ \\
\hline
\end{tabular}

ISSUES AND CONFLICTS

State-local Conflict

As briefly mentioned in the introduction, the statelocal conflict is a serious issue confronted by almost all critical area legislation or other state land use regulations. The local governments play the key role in land use decision-making are very reluctant to increase of state authority in land use matters. The reason for such a resentment may be the high level of bureaucracy at the state level, or the failure of the state in properly carrying out programs in the past, or lack of coordination among various state agencies involved in the process, or lastly lack of 
public participation and local input in decisions that directly effect the communities. Whatever the reason may be in each particular state, the impact of such an attitude toward state intervention has created major obstacles in the effectiveness of a state land use program and a sound statelocal relationship. Even if adopted, state programs have suffered tremendously from improper local administration and enforcement only due to a lack of belief in the approach or other political reasons.

However, some states have managed to be more successful than others due to either a strong state government or extremely fragile environment which has forced local governments to seek assistance and collaboration in an effort to protect and preserve their valuable resources. The state of Rhode Island is among those states with a major state-local conflict. In fact, this conflict is extreme to the point of distrust of the state government. The land management legislation and particularly the critical area section was faced severe local resistance due to their the reluctance to any form of state control in land use decisions. Rural and growing communities that inevitably would have been effected by the legislation were the first ones to seriously oppose the act. On the other hand, most of the cities did not object to the proposed legislation since they were for the most part completely developed and critical area legislation would have had no impact upon their exisiting regulations. 
Table 3.3 is prepared to compare reasons behind 9

some communities' opposition to the legislation.

TABLE 3.3

................

\begin{tabular}{|c|c|c|}
\hline TOWN & CRITICAL CONDITIONS & REASONS EOR OPPOSITION \\
\hline $\begin{array}{l}\text { South } \\
\text { Kingstown }\end{array}$ & $\begin{array}{l}\text { Large portions of } \\
\text { town contains } \\
\text { groundwater supply } \\
\text { areas for South } \\
\text { Kingstown and } \\
\text { Narragansett. }\end{array}$ & $\begin{array}{l}\text { Eear of state control } \\
\text { over large tracts of } \\
\text { land, taking away } \\
\text { responsibilities } \\
\text { from local community. }\end{array}$ \\
\hline \multirow[t]{2}{*}{$\begin{array}{l}\text { North } \\
\text { Kingstown }\end{array}$} & $\begin{array}{l}\text { Quanset Navy Base } \\
\text { Potential area of } \\
\text { major economic } \\
\text { impact. }\end{array}$ & $\begin{array}{l}\text { Parcel is already under } \\
\text { state control through } \\
\text { Port Authority- Eear of } \\
\text { further state control } \\
\text { that would negatively } \\
\text { impact the relationship } \\
\text { w/ the Port Authority. }\end{array}$ \\
\hline & $\begin{array}{l}\text { - Large areas of } \\
\text { open space }\end{array}$ & $\begin{array}{l}\text { - fear of usurption of } \\
\text { state prerogatives and } \\
\text { authority by the state. }\end{array}$ \\
\hline $\begin{array}{l}\text { Burri- } \\
\text { ville }\end{array}$ & $\begin{array}{l}\text { - potential state } \\
\text { reservoir }\end{array}$ & $\begin{array}{l}\text { State already controls } \\
\text { the area, fear of } \\
\text { further state control. }\end{array}$ \\
\hline
\end{tabular}

Table 3.3 clearly illustrates how some Rhode Island communities assume and are fearful of negative consequences of state authority even when some sort of state control already exists. A second reason may be a fear of change of becoming progressive or innovative in land use decisionmaking methods. A critical area program is a new concept in that it calls for the state-local collaboration in the protection of both environmentally and economically critical areas of the commuinities. It also has a comprehensive 
approach to the process of land use decision making rather than a piecemeal and incremental approach. Therefore, the local communities initial reaction to such new ideas and planning strategies is not surprising. However, it seems that lack of clear understanding of the objectives of the program and the means to achieve them may very well be another reason for local resistance. The ambiguity of the legislation in defining the role of the state in relation to the existing role of the local government may cause misjudgments about the program as a whole. Although the process is clear, the details of a state-local effort should be better communicated.

The local resistance was anticipated during the course of preparing the legislation. As the bill evolved, more considerations were given to community participation process: Any group of 50 voters could now nominate critical areas; public hearings were required to help the town or city in the recommendation of critical areas; and the state planning office was required to forward its recommendation along with any written comments on the proposed designation from the effected city or town to the state planning Council.

All these attempts were made to allow for serious local input into the critical areas designation process. 
Public-private Sector Conflict

The effort to increase local involvement in the designation process resulted in a lengthy and time consuming process to which the private developers seriously objected. The solutions to the state-local conflicts, therefore, would create problems for the private sector. Also, the inability to obtain loans on land with potential for critical areas designation was a major dissatisfaction with the proposed program.

The Rhode Island Builders Association (RIBA) and the Rhode Island Chamber of Commerce represented the interest of the members of the community who opposed the increase in local regulatory control in critical area designation. The following is a summary of the private sector concerns in this regard:

1. Only, the town or city council and appropriate state agencies should be allowed to petition for critical areas. In other words, the nomination of critical areas by any group of 50 qualified voters was regarded as a major problem. RIBA believed that since towns and cities are delegated the power to decide upon zoning, critical areas should only be recommended by the local government, and in this case by state agencies.

2. The time element (approximately 1 year) in the designation process is a major concern of the private developers who would not invest in land which is not readily available for use. 
3. The elimination of the legislature's involvement from the process and grant of more discretion to the state planning council. "They (legislators) have strict rules concerning what they may consider and when, they are not neccessarily knowledgable of areas outside their own districts, and they could indefinetely tie a matter up at the request of a special interest group". The increase in the State Planning council discretion would allow for a screening process which would bring the legislature's attention to significant areas likely to be designated as critical. This would undoubtedly shorten the process.

4. The lack of procedure for compensating landowners of 100 acres of land or more; such parcels may fall into critical area classification as "land with development potential" which limits the sale or use of land by the owner. There are no provisions regarding this fairly major issue other than the claim for "taking of private property without just compensation" and judicial proceedings.

5. The broad definition of the critical areas could allow for the use of the program as a tool to prevent development on certain inappropriate sites.

6. The fear of state control over industrial site development because of the critical area review procedures and their designation by the general assembly.

7. Lack of a specific list of potential critical areas throughout the state. Otherwise critical areas designation process could be initiated at any time and for any site and can seriously and unduely delay or restrict 
development of a specific parcel of 1 and.

RIBA and the Chamber of Commerce objections were responded to by considering several alternatives that could be used to address those specific issues. The following recommendations were made:

1. To address the time issue, two alternative solutions were looked at. Firstly, the state Planning Council would have the power to reject the proposed areas that are not truly matters of state concern. This screening process would definitely reduce the time to a more reasonable length. Secondly, time limits could be set up to a certain period each year for both the nomination and review processes by the State Planning Council.

2. To reduce the negative impact of critical areas upon private development, the number of critical areas could be 1 imited each year. This effort would certainly eliminate the funding problems faced by developers. In addition to this, the state could also limit those who can nominate the critical areas which would eliminate potential conflicts with all interest groups in terms of the proper use of a specific parcel of land. Obviously, the second alternative conflicts with the desire of local communities in having more input into the process. Therefore, the compromise can really lie in giving more discretion to the State Planning Council in carrying out a screening process in the initial stages. 
3. To address the compensation issue it was recommended that a section be included in the judicial review chapter which outlined provisions to determine when compensation should be granted. If so, the state must either compensate or reduce the restrictions imposed upon the particular site.

4. The final recommendation is to exclude the critical area chapter from the proposed land management bill and take a piecemeal, special purpose act approach similar to the Coastal Resources Management A.ct and Ereshwater Wetlands Act. In this manner, local communities would have to identify and provide for the management of critical areas within their land management plans and ordinances. Critical areas would be divided into three categories: areas of limited development potential, areas of major public investment, and areas of major economic development potential.

Apart from the special purpose act approach, other alternatives to deal with critical areas are: conservation easements, transfer or purchase of development rights (TDRs or PDR's), land banking, and taxation policies. These methods may be effective but are extremely costly and may not be very feasible to use in each case. Additionally, these methods are more effective on a case-by-case basis. 


$$
N O T E S
$$

1. Rhode Island Statewide Planning Program, REGULATION OE CRITICAL AREAS THROUGH A STATE LAND MANAGEMENT PROGRAM, Technical Paper No. 57, 1975, p.5

2. The American Law Institute, A MODEL LAND DEVELOPMENT CODE, Proposed Official Draft Complete Text and Commentary, 1975, p.296

3. Deller. Thomas, A STUDY OE THE PROPOSED RHODE ISLAND CRITICAL AREA PROGRAM, 1979, p.10

4. The Council of State Governments, A TASK EORCE REPORT, 1975, p. 53

5. Deller, op. cit.,pp.16-17

6. The Council of State Governments, op. cit., p.6

7. Deller, op. cit., p.48

8. ALI, op. cit., p.277

9. Deller, op. cit.,pp.60-61

10. Ibid.,pp.64-67

11. Ibid., P.65

12. Ibid. Pp. $70-72$ 


\title{
Chapter IV \\ CRITICAL AREAS PROGRAMS \\ A COMPARATIVE ANALYSIS AND RECOMMENDATIONS
}

\begin{abstract}
This chapter will summarize the similarities and the differences between the Florida critical area legislation and the proposed Rhode Island critical area provision. The comparative analysis will include the definition, the form of state-local relationship, the designation process, the regulation process and constitutional issues of the critical areas program in the two states. The objective is to determine the shortcomings of the proposed Rhode Island program and to establish a basis to propose a set of recommendations for the Rhode Island program. The Florida's experience in adopting and implementing the critical area program, in the last fifteen years, is a valuable one from which many lessons can be learned. Table 4.1 is a summary table derived from previous chapters.
\end{abstract}

TABLE 4.1

-..........

EL LEGISLATION

-.............

Definition
- Broad definition 3 major categories
State-Local. Local implementation Relationship of state approved regulations
RI PROVISION ..............

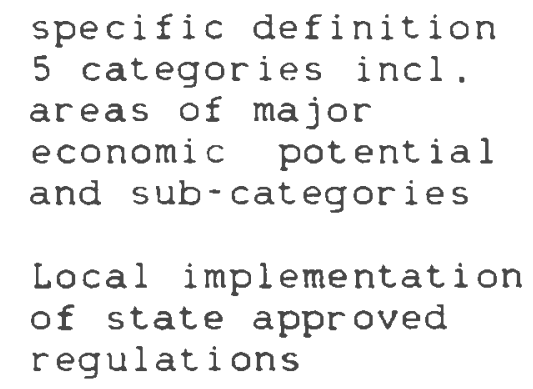
economic potential and sub-categories

Local implementation of state approved regulations 


\begin{tabular}{|c|c|c|}
\hline & EL LEGISLATION & RI PROVISION \\
\hline \multirow[t]{4}{*}{$\begin{array}{l}\text { Administ. } \\
\text { Structure }\end{array}$} & $\begin{array}{l}\text { State planning } \\
\text { agency (governor \& } \\
\text { cabinet) }\end{array}$ & $\begin{array}{l}\text { - State Planning } \\
\text { Council (appointed } \\
\text { by the governor) }\end{array}$ \\
\hline & $\begin{array}{l}\text { - Regional planning } \\
\text { agencies }\end{array}$ & - Not required \\
\hline & $\begin{array}{l}\text { Environmental Land } \\
\text { Management Study } \\
\text { Committee (advisory } \\
\text { commission) }\end{array}$ & - Not required \\
\hline & $\begin{array}{l}\text { Land and Water } \\
\text { Adjucatory Commission } \\
\text { (governor \& cabinet) }\end{array}$ & $\begin{array}{l}\text { - State land appeals } \\
\text { board ( } 2 \text { city or town } \\
\text { representatives) }\end{array}$ \\
\hline \multirow[t]{5}{*}{ Designation } & $\begin{array}{l}\text { State planning } \\
\text { agency recommends } \\
\text { Inventory of land } \\
\text { owned by the state }\end{array}$ & $\begin{array}{l}\text { Division of State } \\
\text { Planning, general } \\
\text { assembly, city or } \\
\text { town, or } 50 \text { voters } \\
\text { can recommend }\end{array}$ \\
\hline & $\begin{array}{l}\text { - Administration } \\
\text { Commission designates } \\
\text { - Legislative veto } \\
\text { power ( } 1980 \text { Amend.) }\end{array}$ & $\begin{array}{l}\text { - State Planning } \\
\text { Council reviews } \\
\text { - Both houses of state } \\
\text { legislature designate }\end{array}$ \\
\hline & $\begin{array}{l}\text { Local comprehensive } \\
\text { plans must conform } \\
\text { with principles for } \\
\text { guiding development }\end{array}$ & . No provision \\
\hline & $\begin{array}{l}\text { Notice to affected } \\
\text { local governments }\end{array}$ & - Public hearing \\
\hline & $\begin{array}{l}5 \% \text { of total state } \\
\text { area }\end{array}$ & \\
\hline \multirow[t]{2}{*}{ Regulation } & $\begin{array}{l}\text { - No development } \\
\text { moratoriums }\end{array}$ & $\begin{array}{l}\text { Development permits } \\
\text { are granted if } \\
\text { essential to public } \\
\text { health, safety and } \\
\text { welfare }\end{array}$ \\
\hline & $\begin{array}{l}\text { Local governments } \\
\text { have } 6 \text { months to } \\
\text { submit regulations }\end{array}$ & $\begin{array}{l}\text { Local governments } \\
\text { have } 6 \text { months to } \\
\text { submit regulations }\end{array}$ \\
\hline
\end{tabular}


EL LEGISLATION

....................

- Failure to submit on time will result in state adoption and enforcement of its own regulations
RI PROVISION

.............

State cannot reject regulations but failure to submit will result in regulations imposed by the appeals board or State Planning Council

- Failure of local governments to amend improper regulations in 180 days will result in new regulations

- When adopted will be . Same administered by local governments

- Eailure to properly . administer can result in a lawsuit by the Judicial review by RI Superior or Supreme Court state planning agency

- Local governments must notify the state planning agency of any development order

Constitut Provision

Act does not

- No Constitutional authorize governClause

ment agencies to adopt regulations or issue orders that are unduly restrictive or constitute a taking of private property

- Act requires reasons for denial of a development permit

Same 


\section{DEFINITION}

The State of Elorida has strictly followed the ALI Model Code pattern in defining the critical areas and has not specifically defined the areas. The definition is broad and allows for a variety of interpretations. In addition, a $5 \%$ cap on all designated critical areas is included. Unlike Florida, the state of Rhode Island has taken a step further in its proposed critical areas definition and has divided the major categories into sub-categories. Also, the definition takes into consideration socio-economic factors as well as physical conditions. Thus, these two states have taken different approaches in this regard and each approach possesses advantages and disadvantages in terms of implementation and constitutionality of the legislation. In the case of proposed legislation, local and privatesector objection to the recommended program is also a matter for debate.

A broad definition is perhaps better accepted while the bill is being proposed, due to the encompassing nature of the categories and its inherent flexibility. However, a more specific description of each category is a key factor in proper designation and enforcement of the regulation. The $5 \%$ designation cap is an interesting and controversial strategy. On one hand, such a ceiling may limit the protection of all resources valuable to the region and the state and therefore it is a major factor weakening the critical area provision. On the other hand, such a limit on state control of private property is desireable and will 
result in less local and private-sector resistance at the initial stages of program adoption, and in less probability of litigation after the legislation is passed.

Here, a middle-range solution is recommended. The program may require the state planning agency to prepare an inventory of all critical areas (approximate location and acreage) in conformance with the state comprehensive plan and to formulate a system of yearly caps similar to the program in Florida which restricted the designation of critical areas to 500,000 acres in the first year of enactment.

This system not only limits the designation of critical areas per year and therefore limits state control of private property but also forces the state to establish priorities in the protection of its resources. Prioritization is a major element in the process of defining and designating a critical area. It will also allow justification in the courts while a hierarchy is established for serving a public purpose and the exercise of police power.

The first years of the program, as demonstrated in the state of Florida, are very critical, and to initially designate the most valuable or endangered resources seems to be the correct approach. The yearly caps can be established for a finite period of 10 years or more to gradually cover all the critical areas but with a pace that is more understandable and acceptable to the private land owners. 
STATE-LOCAL RELATIONSHIP

The ALI Model Code recommendation for local implementation and enforcement of state policy is adhered to by both the states of Florida and Rhode Island where the local governments implement state approved regulations. The state-local system of relationship varies according to the governmental tradition of that particular state. In Rhode Island, local governments have had a strong and active role in development control and would undoubtedly maintain this role if a critical area program were to be adopted.

Whether little or extreme local development control is the tradition of a particular state, the importance of initiating and maintaining a sound and workable syst $m$ of relationship is crucial to the proper implementation o: such a program which calls for a state-local collaboration in all stages. However, the provision of adequate and proper guidelines and principles is the responsibility of the state who should take the initiative in establishing such a relationship and in assisting the local governments.

Although, in theory, the program encourages a complementary role for the state and the local governments in the protection of state resources, the state-lical conflict appears to be a major issue in the state of Rhode Island more so than in the state of Elorida. One major reason for this difference lies in the nature and the degree of Florida's environmental and growth problems which lad forced the local governments to join with the state in 
resolving the situation and presenting the 1972 legislative package.

The Florida's cities and counties took a neutral 1

position but generally supported the bill. In fact, not only the passage of the Florida's legislation was supported by the local governments but it gained the support of both Republican and Democratic parties as well. "The coalition that carried it in both the senate and the house consisted of aggressive urban Democrats and urban Republicans who were ready to face up to the need to better manage Florida's growth". Also, a major developer's support proved to the communities that the legislation does not intend to ban growth but to direct and control it. "Its (Arvida Corporation) active and persistent support throughout the legislative effort did much to add credibility to the notion that the Land Management Act was not simply an effort to stop all growth in Florida".

The proposed land management act in Rhode Island confronted a great deal of resistance to the increase of state land use control. The rural, growing communities, particularly, were convinced that the legislation would stop growth and would effect their tax base negatively. Other reasons for opposing a new land use concept may be fear of change, lack of clarification of state versus local role in the process, lack of understanding of the program's objectives, and the degree of severety of the state's land use problems or the lack of knowledge about it. 
the first solution which eliminates some of these obstacles is a sound state comprehensive planning process. The state of Rhode Island comprehensive plan already exists. This suggests that this state is equiped with a planning tool that determines the present land use issues of the state as well as the future ramification of the present land use system. A complete and updated state comprehensive plan will be an important statement of the state's land use objectives, issues, and process. Maps which illustrate existing natural and man-made features of the state are also included and documented. This will be a useful and important planning tool both for the state and the local governments in terms of critical areas designation.

In order to clarify state land use objectives and their relation to local goals, a more informal yet professional relationship between the state and the local agencies is required. The ALI Model Land Development Code recommends that under the critical area provision, the state planning agency should give proper notice to effected local governments. This notification process can be further refined so to become an informal process by which the state would organize a series of workshops for local governments. These work sessions would serve to discuss and clarify specific planning issues pertaining to each community and to address them with a broad and comprehensive perspective. Another positive outcome from these meetings is the exchange of information which could result in the creation of a 
common database.

With the recent development in office automation, and networking, a database management system can be designed and used at the state level and information can be further updated and completed through the local governments. Whether the system is computerized or not, a common source of information to which both the state and local governments would have easy access would be very useful in the process of critical area recommendation and designation or in other similar programs. In fact, state comprehensive planning could be better implemented if local governments shared the same data sources such as environmental or infrastructure maps and documentations with the state agencies.

\section{ADMINISTRATIVE STRUCTURE}

The basic structure for the administration of the critical areas program is the same for the state of Florida and Rhode Island where the establishment or existence of a land planning agency and a land development appeal board is called for. However, the acting members are different in each state. Unlike Florida 's administrative body consisting of the governor and the cabinet (Administrative Commission), The Rhode Island legisaltion proposes the use of the existing state Planning Council appointed by the governor. Florida appeal board, the Land and Water Adjudicatory Commission, is also consisted of the governor and the cabinet sitting as the Administration Commission. The proposed Rhode Island appeal board, the state land 
appeal board, consists of 7 members appointed by the governor and 2 representatives from the affected city or town.

The Florida legislation also requires the establishment of state and regional advisory commissions, the Environmental Land Management Study Committee, and regional planning agencies. This is an omission in the Rhode Is land provision.

The difference between the administrative structure of these two programs is two fold. Eirstly, Elorida's program is directly administered by the governor and the cabinet by which all the appeals are also heard. It might be stated that Rhode Island proposed a more democratic system of critical area administration by calling for the participation of the cities and towns in the process. This, in a way, would compensate for the absence of an advisory commission in the proposed Rhode Island proposed administrative structure. On the other hand, the direct involvement of the Governor in the process of designation and implementation, such as in Florida, is a major political advantage. Therefore, it can be concluded that the membership of the administrative structure is almost dictated by the traditional political structure of the particular state.

Secondly, Florida's considerations for regional planning and the involvement of regional planning agencies and regional advisory commissions indicates a better division of responsibilities between the state and regional 
bodies, and a broader perspective on the process of critical areas designation and regulation. Also, the participation of regional agencies and their assistance is a bridge that fills the gap between the local governments and the state. Rhode Island may not require the same degree of involvement of regional agencies due to its small size. However, the concept of regionalism and the regional coloring of land use planning can be useful to the protection of resource areas beyond the local jurisdictions.

The Rhode Island program intended to assign the existing State Land Planning Council which is part of the Rhode Island State Planning Program as the critical area administrative agency. Although the state Planning Council should take an active role in such a process, however, the establishment of a new commission, specifically, may better ensure the effectiveness of the program. Therefore the creation of a land use commission was recommended by the State Planning Program. "This land use commission would be set up as an independent agency in the state organizational structure. It would be seperate because its function and duties would be different from those of any existing agency and because many of its functions would require it to have a viable working relationship with other state agencies".

The commission would consist of three public members appointed by the governor, two local government officials chosen by the Rhode Island League of Cities and Towns, a statewide organization of local government officials, or by 
the governor, three state legislators, two of whom would be state representatives. The last seven positions on the commission would be occupied by the heads of state agencies.

The establishment of a special commission with the sole. responsibility of critical areas administration in lieu of using an existing agency is advantageous as it improves the proposed program in terms of time consumption and procedural difficulties of the process.

\section{DESIGNATION}

The designation process differs between Florida and the proposed Rhode Island legislation. In Florida, the state planning agency initiates the critical areas designation process by recommending an area. In Rhode Island, the process would also begin if any member of general assembly, city or town, or 50 qualified voters would feel the necessity of nominating an area for critical area designation. In Florida the designation is made by the Administration Commission (governor and cabinet), whereas in Rhode Island the houses of legislature would designate a critical area after the state Planning Council review.

In terms of constitutionality, the Florida statute was declared invalid in the courts due to the delegation of excessive legislative power to an administrative body, and as a result, the legislature gained a veto power on the designation of critical areas. The Rhode Island proposed legislation possessed those attributes that courts have generally held valid in terms of delegation of legislative 
power. The Rhode Island program also allowed for more public participation where the local governmental unit or other interest groups could initiate the designation process as opposed to Florida provision which allows limited standing. However, the legislature's direct involvement in the process and the broad standing of the was seriously objected to by the business community in Rhode Island. The developers believed that the grant of more discretion to the State Planning Council would result in a screening process which will shorten the designation process. Also they opposed the provision for 50 qualified voters being able to initiate the critical areas designation.

Therefore, in terms of the nomination of critical areas, and more standing by interest groups, the state of Rhode Island has followed the ALI recommendation more closely than that the Florida legislation. The 1978 court ruling in Florida demonstrates the importance of a well thought out process that serves the needs and objectives of both the state government and the state legislature. Whether the administrative body or the legislature designates an area, the legislature's intent must be clear and policies must be set for the administrative body to perform accordingly and to properly implement the set policies.

In order to address both the constitutional issues and the business community's concern, Florida's imposition of legislative veto power on the decision of an administrative body appears to be a possible solution for 
the state of Rhode Island.

As recommended by the ALI Model Code, boundaries of critical areas must be specified, reasons for designation and dangers of uncontrolled or inadequate development must be stated, and most importantly, general "principles for guiding development" must be developed. Elorida amended its critical area legislation to better deal with these issues (see Chapter II). Specifically, Florida required the local government comprehensive plans to conform with the "principles for guiding development".

The Florida experience in the designation of critical areas also reveals that a legislative provision for a "dedesignation" process after the proof of proper formulation, adoption and administration of regulations by the local governments may increase the constitutionality of the statute, and lessen the probability of litigation. In other words, a critical area law may provide for the dedesignation of an area if the local governments adopted comprehensive plans in accordance to the state "principles for guiding development" and proper critical areas regulations. It is only then that the state can reassess the possibility for a lifting of the designation.

This study therefore, recommends the following process of designation which combines the recommendations of the ALI Model Code and Florida's experience and integrates them into the Rhode Island proposed program:

1. Division of State Planning, general assembly, city or town, or 50 qualified voters recommend an area. 
2. The state planning agency (land use commission) notifies the affected local governments.

3. Submission of the recommendations must be detailed and include the specific reasons for designation.

4. The State Planning Council reviews the recommendations and if approved, the exact boundaries must be specified and "principles for guiding development" must be established.

5. An inventory of land owned by the state must be submitted.

6. The state planning agency designates the critical area with legislative veto power.

7. Based upon the state comprehensive plan, yearly caps on designation of critical areas must be established.

8. Conditional dedesignation after a finite period must be provided for.

\section{REGULATION}

The regulation process in the two states is very similar and follows the same timeframe i.e., six months for local governments submission of proper regulations. Also, both states include judicial review in case local governments fail to properly administrater and enforce regulations. Florida also provides that the state planning agency is capable of initiating a lawsuit if local enforcement was inadequate. Local governments must also notify the state planning agency of any development order. The role of the state in the regulation process is intended to be an advisory/supervisory role which ensures 
the adoption of reasonable regulation consistent with state policies. The proposed Rhode Island law did not grant the authority of reject the regulations submitted by the local governments to the state but required state review and a public hearing before the adoption of the regulations. In Florida, the law provides that if no regulations were adopted by the local governments or the state, the designation is to be terminated and no additional areas be designated for 12 months.

The Florida legislation does not provide for any form of development moratoriums or interim freeze between the time of recommendation of an area for designation and adoption of the regulations. Therefore, in the extensive period of time purposely given to the local and regional agencies for regulation formulation, any development in conformance with the existing local regulation is perfectly acceptable even if it were against the critical areas program objectives. This is one of the major weaknesses of the Florida legislation which can be corrected by including an interim development freeze provision. As mentioned in chapter II, many courts have upheld the imposition of such moratoriums as a reasonable exercise of police power if it were for a finite period and had a public purpose.

The degree of effectiveness of the regulations and thus the implementation of the program depends upon the existence or the availability of the following: 
1. A set of state guidelines and standards;

2. Complete state and regional assistance and support to the local governments in formulating regulations;

3. The support of an adequate number of qualified and competent staff at the state, regional, and local level;

4. Development moratoriums designed for a limited period of time;

5. A strong system of enforcement of regulations either by the zoning boards or other local administrative bodies;

6. An effective and simple process of state review of the development orders and appeals if they did not meet the "Principles for Guiding Development"; and

7. A state monitoring system on the actions of the local governments

CONSTITUTIONAL PROVISIONS

The following elements derived from Elorida's experience in the courts, are necessary to establish the validity of a critical area statute.

1. A constitutional clause such as "the law is not to be construed as enhancing or diminishing the rights of property owners under the U.S. or State Constitution";

2. The existence of a public purpose such as the protection of public health, safety, and general welfare, and a provision or clause for compensation for the taking of private property. "No private property shall be taken except for a public purpose and full compensation paid therefore to each owner; 
3. The existence of an alternative, reasonable use even if very limited, or absolute but for a limited period of time; 4. The existence of a comprehensive plan to which plans and regulations must conform;

5. Provision for the proper delegation of legislative power to an administrative body;

6. The broadening of standing in recommending critical areas so to include interest groups and more public participation; 7. The statement of reasons in detail for denial of a development permit;

8. The provision of judicial as well as administrative review and appeal process;

9. Caps on the designation of the critical areas which indicates a limit on the control of land by the state and the provision of a dedesignation mechanism; and

10. In case of development moratoriums, the extend of time along with a reasonable public purpose.

\section{SUMMARY OF RECOMMENDATIONS}

In concluding this study, this chapter will briefly summarize all the recommendations made throughout the previous chapters with regard to procedural requirements, political conflicts, and legal constraints. Although a difficult task, these recommendations attempt to tailor the Rhode Island critical areas program to the needs and objectives of all interested parties, the state, the local communites, and the private sector whose conflicting 
interests, in some instances, have caused the failure of the legislation. Additionally, the procedural difficulties and shortcomings in the legislation have been another reason for opposition and thus rejection of the program.

The recommendations $l$ isted below are derived from the Florida's experience, the Rhode Island Builders Association commentary, other litterature concerning program design and implementation, and the author's input. The organization of these recommendations follows the order in the previous chapters.

1. At the local level, the Program should be adopted pursuant to zoning and subdivision control, and local comprehensive planning enabling acts. At the state level, the Program should be part of a legislative package along with other legislation such as Floodplain and Wetland Protection, Coastal Resources Management, or the like. The adoption of the gpProgram should definitely follow a state comprehensive planning enabling act and a provision for periodic update of the comprehensive plan.

2. The definition of critical areas should neither be too broad nor too specific.

3. the program should encourage both formal and informal state-local relationship. The informal process can be achieved through workshops for the affected local governments. 
4. The program should require the establishment of a new and special commission, such as the recommended land use commission, as the administrative agency.

5. Regional planning agencies' involvement is necessary to bridge the gap between local and state agencies.

6. Prior to designation, a specific list of potential critical areas (location and acreage) with a statement of priorities among those areas should be prepared. Also an inventory of state-owned land areas should be provided by the state planning agency.

7. The program should be cost-effective through maximizing the use of existing data, and exchanging of information between state, local agencies and other interest groups. A centralized database management system and networking would serve this purpose.

8. The program should be designed to be efficient and less time consuming. The State Planning Agency might set up time limits to certain period each year for nomination and review processes.

9. A statement of reasons for the designation of an area as well as the denial of development permits should always be included.

10. The state planning agency should provide a detailed set of guidelines and standards for local governments to follow in formulation of the critical areas regulations. 
11. The program should have provision for yearly caps on the number of or their acreage for a limited period of time.

12. The program should have a provision and a recommended procedure for conditional dedesignation.

13. A state monitoring and enforcement should be developed which can be stengthened by periodic air photos or air surveillance, field inspection, and involvement of interested groups to assist in monitoring.

14. The participating local, regional, and state agencies should have the support of adequate number of qualified and competent professional staff.

15. The program should include a constitutional clause.

16. The program should require the adoption of regulations that satisfy the due process requirements such as the existence of a reasonable public purpose.

17. The program should provide for the existence of an alternative, reasonable use for the designated critical area by excluding from restriction those classes of use and development consistent with the objectives of the program. Performance standards for permitted uses should be included.

18. The program should provide for both administrative and judicial review and appeal process. 
19. The program should promote more communication between the state, local agencies, and the business community similar to the DRI rpocess which is proven to possess more flexibility and potential for a higher level of communication and private-public negotiations.

20. The critical areas program objective in protecting the resource areas with a statewide significance would be better achieved if the program is adopted simoultaneously with the DRI program whose role is complementary to the Areas of Critical State Concern (ACSC) program. 
$N O T E S$

1. Degrove, John M., LAND, GROWTH, AND POLITICS, 1984, p.115

2. Ibid.

3. Ibid.

4. Rhode Island planning program, REGULATION OF CRITICAL AREAS THROUGH A STATE LAND MANAGEMENT PROGRAM, Technical Paper $\# 57,1975$, pp.84-95

5. Ibid. 


\section{BI BL IOGRAPHY}

Carr, James H., and Dusesing, Edward E., LAND USE ISSUES OE THE $1980^{\circ} \mathrm{S}$, New Jersey: The Center for Urban Policy Research, 1983

Carter, Luther J., THE FLORIDA EXPERIENCE, Baltimore \& London: John Hopkins Press, 1974

Degrove, John M., LAND, GROWTH, AND POLITICS, Washington, D.C., Chicago, Illinois : American Planning Association, 1984

- Deller, Thomas E., RHODE ISLAND CRITICAL AREAS PROGRAM, (thesis project) Kingston, Rhode Island: University of Rhode Island, 1979

Florida Environmental Land and Water Management Act, Florida Statutes, Chapter 380, Sections $380.05,1972$

Healy, Robert G., and Rosenberg. John S., LAND USE AND THE STATES, Baltimore and London: John Hopkins Press for Resources for the Future Inc., 1979

Jackson, Richard H., LAND USE IN AMERICA, New York: V.H. Winston \& Sons, 1981

Kusler, Jon A., REGULATING SENSITIVE LANDS, Environmental Law Institute, Washington, D.C.: Balinger Publishing Company, 1980

Lounsbury, John F., Sommers, Lawrence M., and Fernald, Edward A., LAND USE, A SPACIAL APPROACH, Duruque, Iowa: Kendall/Hunt Publishing Company, 1982

Myers, Phyllis, SLOW START IN PARADISE, Washington, D.C.: The Conservation Eoundation, 1974

Rhode Island Legislature, AN ACT ESTABLISHING A STATELOCAL LAND MANAGEMENT PROGRAM, 77-h 6299 (Substitute "A"), 1978

Rhode Island Statewide Planning Program, REGULATION OF CRITICAL AREAS PROGRAMS THROUGH A STATE LAND MANAGEMENT BILL, technical paper No 57, Providence, Rhode Island: Statewide Planning Program, 1975

The American Law Institute, A MODEL LAND DEVELOPMENT CODE, Proposed Official Draft Complete Text and Commentary, Philadelphia, Pennsylvania:ALI, 1975 
The American Law Institute, A MODEL LAND DEVELOPMENT CODE, Tentative Draft No 3, Philadelphia, Pennsylvania: ALI , 1971

The Council of State Government, ISSUES AND RECOMMENDATIONS-STATES CRITICAL AREA PROGRAMS, Land Use of State Government, 1975 